\title{
New Records of Vascular Plants in the Yukon Territory VII
}

\author{
William J. Cody ${ }^{1}$, Bruce A. Bennetr ${ }^{2}$, and Phil Caswell ${ }^{3}$
}

1 Biodiversity, National Program on Environmental Health, Agriculture and Agri-Food Canada, Wm. Saunders Building (49), Central Experimental Farm, Ottawa, Ontario K1A 0C6 Canada

2 Department of Environment, Government of the Yukon, Box 2703, Whitehorse, Yukon Y1A 2C6 Canada; e-mail: Bruce. Bennett@gov.yk.ca

3 deceased

William J. Cody, Bruce A. Bennett, and Phil Caswell. 2005. New records of vascular plants in the Yukon Territory VII. Canadian Field-Naturalist 119(3): 417-436.

Based on field reconnaissance mainly in 2003 in Kluane National Park but also many other areas throughout the Yukon, information is provided on geographically significant plant occurrences. Thirteen native taxa, Agrostis humilis, Blysmopsis rufa, Carex bebbii, C. lenticularis var. dolia, C. nigricans, C. sartwellii, C. siccata, Diphasiastrum sitchense, Najas flexilis, Oxytropis arctica var. arctica, Oxytropis arctica var. murrayi, Saxifraga nelsoniana ssp. carlottae and Swertia perennis and two introduced taxa, Bromus japonicus and Leymus mollis ssp. mollis s.l. are reported new to the flora of the Yukon Territory. Significant range extensions for 109 native and eight introduced taxa are included and three species, Clematis occidentalis, Polygonum persicaria, and Verbena hastata are deleted from the flora.

Key Words: Vascular plants, Yukon Territory, flora, new records, range extensions, phytogeography.

Since the writing of New Records of Vascular Plants in the Yukon Territory VI (Cody et al. 2004), a considerable number of plant specimens have been submitted to Cody for identification and confirmation. The major submissions include the following locations and collectors: (1) Kluane National Park and vicinity by Phil Caswell and Bruce A. Bennett for the National Park Service as part of ongoing botanical inventories; (2) various locations by Reidar Elven and Heidi Solstad visiting from the University of Oslo, Norway; (3) Bruce A. Bennett collected plant specimens from throughout the territory; and (4) Greg Brunner from the Dawson City area.

This paper serves to further update the Flora of the Yukon Territory (Cody 1996) and Flora of the Yukon Territory, Second Edition (Cody 2000) along with other records recently published (Cody et al. 1998, 2000, 2001, 2002, 2003, 2004). The floristic information presented earlier and updated here provides the basis for biological research and ongoing work relating to wildlife management, forestry, sustainable resource management and agriculture. With additions of thirteen native and two introduced species reported here the flora now includes 1195 species.

The taxa addressed in the body of this paper appear in a synoptic list by Yukon status in alphabetical order. The taxa are then discussed in taxonomic order, as presented in the Flora of the Yukon Territory with citation of specimens and other pertinent information. Common names follow Cody (1996), Douglas et al. (19982001) and Kartesz and Meacham (1999).

\section{Synoptic List by Yukon Status}

Native Taxa New to the Yukon Territory (13):

Agrostis humilis

Blysmopsis rufa (Scirpus rufus)
Carex bebbii

Carex lenticularis var. dolia

Carex nigricans

Carex sartwellii

Carex siccata

Diphasiastrum sitchense (Lycopodium sitchense)

Najas flexilis

Oxytropis arctica var. arctica

Oxytropis arctica var. murrayi

Saxifraga nelsoniana ssp. carlottae

Swertia perennis

Introduced Taxa New to the Yukon Territory (2):

Bromus japonicus

Leymus mollis ssp. mollis s.1.

\section{Range Extensions of Native Taxa within the}

Yukon Territory (109):

Angelica lucida

Antennaria pulcherrima

Aphragmus eschscholtzianus

Apocynum androsaemifolium

Arabidopsis salsuginea

Arabis boivinii

Arnica diversifolia

Arnica latifolia

Artemisia tilesii

Astragalus alpinus

Athyrium filix-femina var. cyclosorum

Campanula rotundifolia

Carex brunnescens

Carex buxbaumii

Carex canescens

Carex eburnea

Carex lasiocarpa

Carex laxa

Carex lenticularis var. lipocarpa

Carex livida

Carex microglochin

Carex microptera 
Carex nardina

Carex parryana

Carex phaeocephala

Castilleja miniata

Castilleja parviflora

Castilleja unalaschcensis

Cirsium foliosum

Coeloglossum viride ssp. bracteatum

Comandra umbellata ssp. pallida

Cryptogramma crispa var. sitchensis

Douglasia ochotensis

Draba albertina

Draba cinerea

Draba crassifolia

Draba lonchocarpa var. vestita

Draba nivalis

Draba oligosperma

Draba scotteri

Draba stenoloba

Draba stenopetala

Drosera anglica

Dryas integrifolia ssp. crenulata (Dryas crenulata)

Dryas octopetala ssp. hookeriana (Dryas hookeriana)

Epilobium hornemannii ssp. hornemannii

Erigeron grandiflorus ssp. arcticus

Erigeron humilis

Erigeron peregrinus ssp. peregrinus

Erigeron pumilus

Erigeron uniflorus ssp. eriocephalus

Erigeron yukonensis

Eriophorum gracile

Festuca brachyphylla

Festuca brevissima

Festuca minutiflora

Galium triflorum

Geranium erianthum

Harrimanella stellariana

Hieracium gracile

Iris setosa ssp. interior

Juncus bufonius

Juncus filiformis

Leptarrhena pyrolifolia

Luetkea pectinata

Lupinus nootkatensis

Luzula piperi

Luzula spicata

Menyanthes trifoliata

Minuartia dawsonensis

Myriophyllum verticillatum

Nuphar variegatum

Orobanche fasciculata

Oxytropis campestris ssp. jordalii

Oxytropis nigrescens ssp. nigrescens

Papaver radicatum ssp. kluanensis

Parnassia fimbriata

Phippsia algida

Phyllodoce $\times$ intermedia

Pinus contorta ssp. latifolia

Plantago eriopoda

Polemonium pulcherrimum

Polygonum achoreum

Polygonum lapathifolium

Polystichum lonchitis

Potamogeton praelongus

Potentilla bipinnatifida
Primula nutans

Rosa woodsii

Rumex maritimus ssp. fueginus

Sagina nivalis

Salix niphoclada

Saxifraga nelsoniana ssp. pacifica

Saxifraga rufopilosa

Schoenoplectus acutus (Scirpus acutus)

Schoenoplectus tabernamontani (Scirpus validus)

Tricaphorum alpinum (Scirpus hudsonicus)

Silene acaulis ssp. subacaulescens

Sorbus sitchensis

Stellaria umbellata

Symphyorichum ciliatum (Aster brachyactis)

Symphyorichum yukonense (Aster yukonensis)

Taraxacum lyratum

Typha latifolia

Triantha glutinosa

Utricularia minor

Valeriana sitchensis

Veronica americana

Viola adunca

Range Extensions of Introduced Taxa within the Yukon Territory (8):

Alopecurus geniculatus

Alopecurus pratensis

Avena sativa

Phalaris arundinacea

Polygonum convolvulus

Psathyrostachys juncea

Secale cereale

Vicia americana

Comments on Native Taxa in the Yukon Flora (2):

Lonicera involucrata

Saxifraga nelsoniana ssp. carlottae

Deletions of Native Taxa from the Yukon Flora (4):

Clematis occidentalis

Lonicera involucrata

Polygonum persicaria

Verbena hastata

\section{LYCOPODIACEAE}

Lycopodium sitchense Rupr. (L. sabinifolium Willd. ssp. sitchense (Rupr.) Calder \& Taylor, Diphasiastrum sitchense (Rupr.) Holub), Sitka Club-moss - YUKON: Kluane National Park, Fisher Glacier near Alsek River, $\mathrm{W}$-facing slope above valley glacier leading into Fisher Glacier, $60^{\circ} 08^{\prime} 16^{\prime \prime} \mathrm{N} 138^{\circ} 13^{\prime} 28^{\prime \prime} \mathrm{W}$, B. A. Bennett 03983, 7 July 2003 (DAO); Kluane National Park, Alsek River, ca. $38 \mathrm{~km}$ SW of Haines Junction, $1245 \mathrm{~m}$ in alpine Festuca altaica community, coarse soil, well drained aspect N62E slope $5 \% 60^{\circ} 28^{\prime} \mathrm{N} 137^{\circ} 52^{\prime} \mathrm{W}$, G. W. Douglas \& M. J. Ratcliffe 10779, 8 July 1978, on mixed sheet with Diphasiastrum alpinum, determined by B. A. Bennett, confirmed by A. Ceska. (Specimen housed at the Royal BC Museum V137472).

The map in Hultén (1968) had a dot in the southwest of the Yukon which Cody (1996) considered to be a misidentification. Cody (1996) suggested that it should be looked for in that area and the specimens cited above is a verification. 


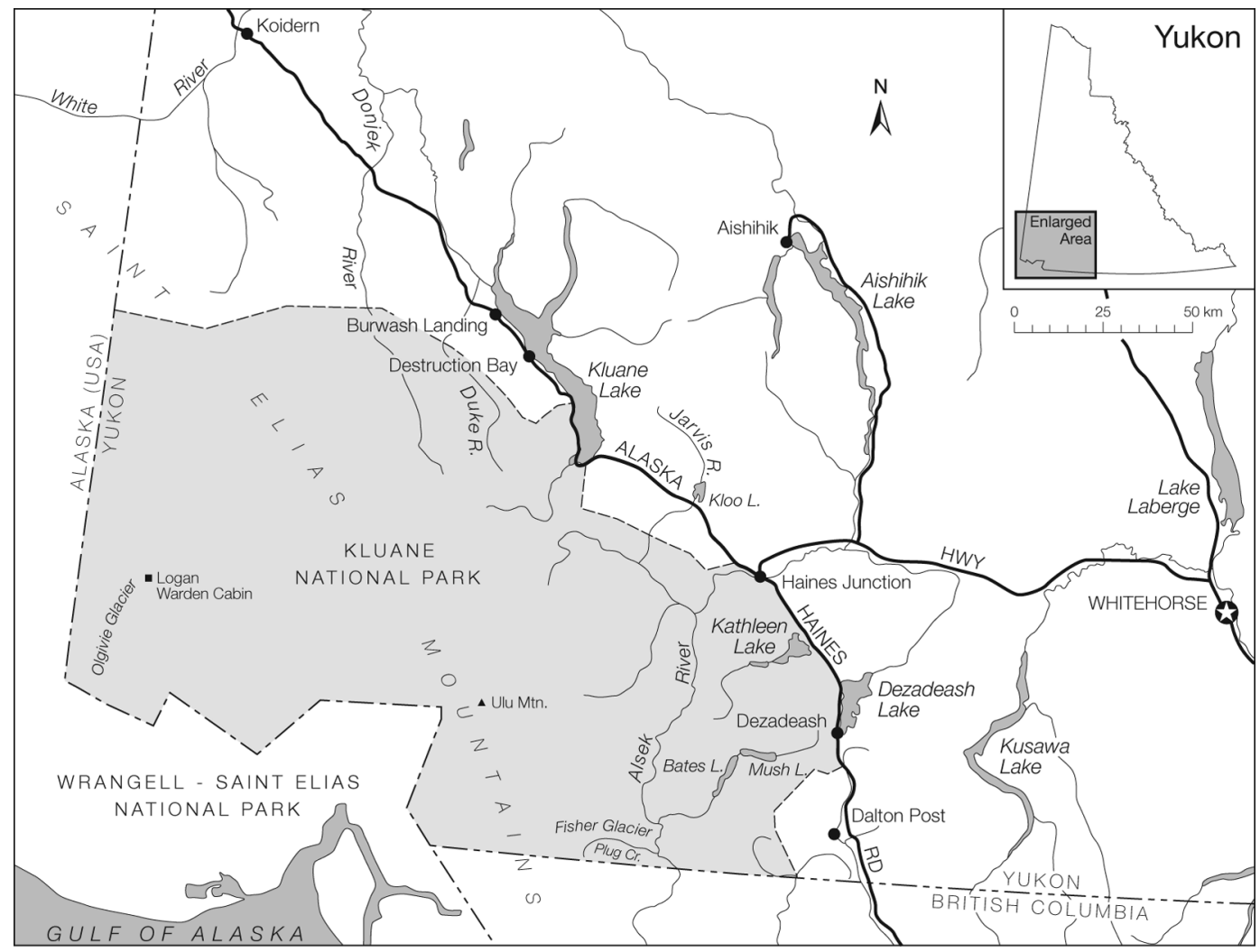

FIGURE 1. Locator map - Southwest Yukon (courtesy of the Yukon Territorial Government).

\section{PTERIDACEAE}

Cryptogramma crispa (L.) R.Br. var. sitchensis (Rupr.) C. Christensen, Sitka Parsley Fern. - YukON: Kluane National Park, Fisher Glacier near Alsek River, Wfacing slope above valley glacier leading into Fisher Glacier, mid-slope in large talus, thin soil of silty sand with rock outcrop, $60^{\circ} 08^{\prime} 16^{\prime \prime} \mathrm{N} 138^{\circ} 13^{\prime} 28^{\prime \prime} \mathrm{W}, B$. A. Bennett 03-1000, 7 July 2003 (DAO); Fisher Glacier near Alsek River, NE of base camp, under boulders in steep unvegetated draws on south-facing slope, $60^{\circ} 08^{\prime} 31^{\prime \prime N} 138^{\circ} 13^{\prime} 13^{\prime \prime W}$, B. A. Bennett 03-1069, 8 July 2003 (DAO).

Douglas et al. (1981) did not include this fern in the Rare Vascular Plants of the Yukon but Cody (1996) knew it from only three sites adjacent to the Canol Road. The specimens cited above are an extension of the known range in the Territory of about 325 kilometers south of a site adjacent to the South Canol Road and are new to Kluane National Park.

\section{ASPIDIACEAE}

Athyrium filix-femina (L.) Roth var. cyclosorum (Ledeb.) Moore, Lady Fern - Yukon: moist organic soil, meadows in thickets, east Haines Hwy. at Km 152, $60^{\circ} 02.970^{\prime} \mathrm{N} 136^{\circ} 53.001^{\prime} \mathrm{W}$, P. Caswell 03-747, 21 Aug. 2003 (DAO); Kluane National Park, Fisher Glacier near Alsek, NE of base camp, under boulders in steep unvegetated draws on south-facing slope where it was rare, $60^{\circ} 03^{\prime} 31^{\prime \prime} \mathrm{N} 138^{\circ} 13^{\prime} \mathrm{W}$, B. A. Bennett 031062, 8 July 2003 (DAO).

This species was considered rare in the Territory by Douglas et al. (1981) and Cody (1996). The first specimen cited above is from a site about 60 kilometers east of a site mapped by Cody (1996) in southern Kluane National Park. The second specimen is from a site about 20 kilometers northwest.

Polystichum lonchitis (L.) Roth., Holly Fern - YUKON: Kluane National Park, Fisher Glacier near Alsek River, NE of base camp, under boulders in steep unvegetated draws on south-facing slope, where it was rare, $60^{\circ} 08^{\prime} 31^{\prime \prime N} 138^{\circ} 13^{\prime} 13^{\prime \prime} \mathrm{W}$, B. A. Bennett 03-1061, 8 July 2003 (DAO).

This species was considered rare in the Yukon by Douglas et al. (1981) and Cody (1996) where it was only known from two widely separated localities. The specimen cited above is an extension of about 30 kilometers northwest of a previously known site in Kluane National Park adjacent to the British Columbia border.

\section{PINACEAE}

Pinus contorta Dougl. ex Loud. ssp. latifolia (Engelm.) Critchfield, Lodgepole Pine - YUKON: open slope west of the road, only single large old tree at least $10 \mathrm{~m}$ tall; appears to pre-date the construction of the highway, 
appearing natural, Haines Road Km 157, south of Million Dollar Falls, 6005'27"N 136 55'01", B. A. Bennett 03-003, 27 April 2003 (DAO).

The specimen cited above is the southernmost yet found in the southwest of the Territory. It is from a site about 30 kilometers south-southeast of a site reported by Cody et al. (2003) adjacent to the St. Elias Trail in Kluane National Park.

\section{TYPHACEAE}

Typha latifolia L., Common Cattail - YuKON: extensively placer mined area, Lower Hunker Creek area east of Dawson City, 64 $01^{\prime} \mathrm{N} 139^{\circ} 03^{\prime} 01.2^{\prime \prime W}$, G. Brunner 594, 7 Sept. 2003 (DAO); Gravel around and in small pond with scattered Salix, Carex, and Schoenoplectus, up Hunker Creek Road east of Dawson Creek, 6401'11.9"N 13908'57.8"W, Peterson 18518, Saarela and Smith, 11 July 2004 (DAO).

The specimen cited above is an extension of the known range of this rare species in the Territory of about 175 kilometers northwest of Mayo.

\section{Potamogetonaceae}

Potamogeton praelongus Wulf., White-stemmed Pondweed - YUKON: floating on surface of lake, Pine Lake, $60^{\circ} 43.015^{\prime} \mathrm{N} 137^{\circ} 28.287^{\prime} \mathrm{W}$, P. Caswell 03-491, 23 July 2003 (DAO).

Douglas et al. (1981) considered this taxon rare in the Territory. The specimen cited above is an extension of the known range of about 60 kilometers north of a site reported by Cody et al. (2000).

\section{NAJADACEAE}

Najas flexilis (Willd.) Rostk. \& Schmidt, Wavy Water Nymph (Figure 2) - YUKON: meso-eutrophic lake and mesotrophic mire, west side of Wye Lake, Watson Lake, $60^{\circ} 07^{\prime} \mathrm{N} 128^{\circ} 48^{\prime} \mathrm{W}, \mathrm{R}$. Elven \& H. Solstad 031301, 29 Aug. 2003 (DAO).

This is a new species in the flora of the Yukon Territory which should be added to the list of rare plants (Douglas et al. 1981). Najadaceae can be separated from Potamogetonaceae as follows:

A. Flowers solitary in the leaf axils;

leaf margins minutely serrulate with

35-80 teeth per side ............ Najadaceae

A. Flowers born on spikes or racemes;

leaf margins entire ......... Potamogetonaceae

Najas flexilis can be described as follows: Submerged, annual monoecious, slender-stemmed, bushy or elongate, and often forming extensive beds; leaves numerous, becoming more crowded toward the branch tips, narrow, $1-3 \mathrm{~cm}$ long, mostly less than $1 \mathrm{~mm}$ wide, gradually tapering to a sharp point, minutely toothed; flowers unisexual, born in the axils of the branches and from the sheaths of leaf-bases; anthers 1-celled; pistils mostly with 3 stigmas; fruit and seed narrowly ovoid or elliptic, 2-3 mm long; seed entirely filling the fruit, shiny, reddish-brown.

In Canada, this species is known from Newfoundland to British Columbia; the nearest known site to that cited above is in Wood Buffalo Park just south of Fort Smith (Porsild and Cody 1980).

POACEAE

Agrostis humilis Vasey, (Agrostis thurberiana Hitchc., Podagrostis thurberiana (Hitchc.) Hultén), Alpine

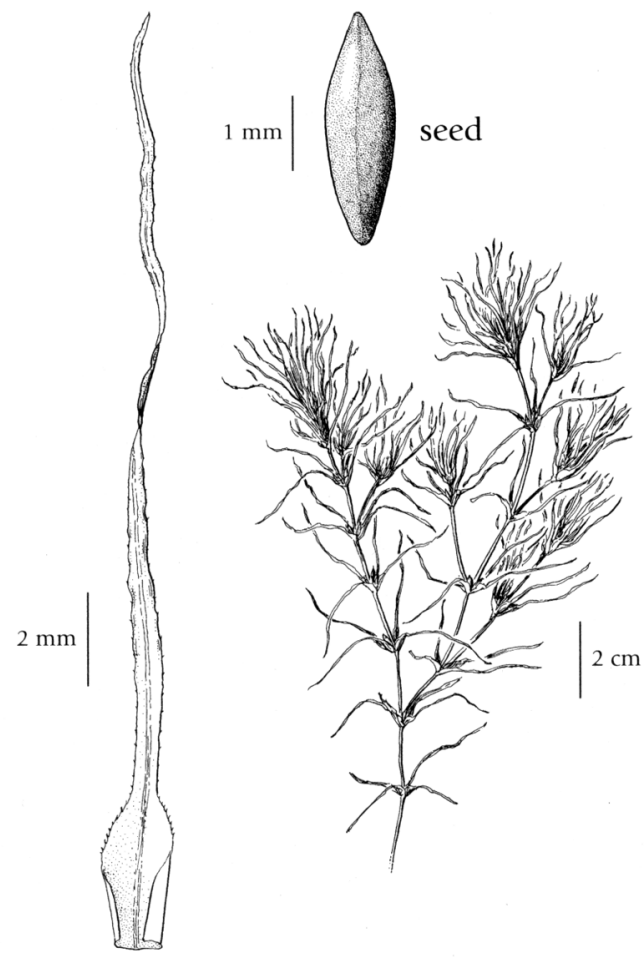

FIgURE 2. Najas flexilis (Willd.) Rostk. \& Schmidt, Wavy Water Nymph (illustration by J. R. Janish courtesy of the University of Washington Press).

Bentgrass (Figure 3) - YuKON: Kluane National Park, rare in open herbaceous and graminoid meadows of south-facing mid-slopes in drier patches of open soil, Fisher Glacier near Alsek River, NE of base camp, 600' $31^{\prime \prime N} 138^{\circ} 13^{\prime} 13 " \mathrm{~W}$, B. A. Bennett 03-1073, 8 July 2003, (DAO); Kluane National Park, Shursho Lake, meadow near lake, $100 \%$ vegetative coverage, moist organic soil, $60^{\circ} 03.6^{\prime} \mathrm{N} 137^{\circ} 23.8^{\prime} \mathrm{W}, P$. Caswell \& R. Maraj 04-427, 4 August 2004 (DAO) (determined by S. J. Darbyshire).

Agrostis humilis can be described as follows: Perennial tufted or matted grass from fibrous roots; stems $5-30 \mathrm{~cm}$ tall; leaves about $2.5 \mathrm{~mm}$ broad, panicle narrow; spikelets about $2 \mathrm{~mm}$ long, violet; lemmas 1.5-2.3 mm long, awnless; rachilla minutely pubescent; paleas present, at least half as long as the lemmas, anthers about (0.5) 06-0.8 mm long.

This species is new to the flora of the Yukon Territory and should be added to the list of rare plants in the Territory. It is frequent in the subalpine and alpine zones throughout British Columbia, and extends into southern Alberta and south to California, Nevada, Utah and New Mexico. Agrostis gigantea and $A$. capillaris are rhizomatous; however, $A$. humilis is caespitose, so is more closely related to A. scabra and $A$. exarata. It can be separated from Agrostis scabra and Agrostis exarata as follows:

A. Paleas present, at least half as long as lemmas $\ldots \ldots \ldots \ldots \ldots \ldots \ldots$. humilis

A. Paleas absent or less than half as long as lemmas A. scabra and A. exarata 
Alopecurus geniculatus L., Water Meadow-foxtail YUKON: Fort Selkirk, $62^{\circ} 47^{\prime} \mathrm{N} 137^{\circ} 23^{\prime} \mathrm{W}$, J. B. Tarleton, Summer 1899 (US).

This species, which is introduced in Canada from Eurasia, was reported as new to the Territory (Cody et al. 2003) from Horseshoe Slough. It is common in SW British Columbia north to the Queen Charlotte Islands. The above collection was reported by Britton and Rydberg (1901) and is a range extension of $130 \mathrm{~km}$ to the southwest.

Alopecurus pratensis L., Meadow Foxtail - Yukon: uncommon in moist areas between fence and highway, Takhini Salt Flats, $60^{\circ} 51^{\prime} 23 " \mathrm{~N} 135^{\circ} 42^{\prime} 55^{\prime \prime} \mathrm{W}, B$. A. Bennett, R. Elven \& H. Solstad 03-086, 26 Aug. 2003 (B. A. Bennett Herbarium, photo DAO).

This is an introduced species that is not yet common in the Territory. The nearest known site to that listed above is about 60 kilometers south of Whitehorse.

Avena sativa L., Oats - YUKON: moist, gritty organic soil, Alaska Hwy., about 30 kilometers northwest of Haines Junction in squirrel research area, $60^{\circ} 57.110^{\prime} \mathrm{N}$ $138^{\circ} 02.388^{\prime} \mathrm{W}$, P. Caswell 03-563, 8 Aug. 2003 (DAO).

Cody (1996) knew this introduced species from only three sites in the Territory (the vicinity of Mayo, North Canol Road and east of Watson Lake). An additional site was found by Cody in the vicinity of Whitehorse (Cody et al. 2004).

Bromus japonicus Thunb. ex Murray, Japanese Brome (Figure 4) - YukON: highway embankment, Alaska Hwy. at Jarvis River Bridge, $60^{\circ} 55.349^{\prime} \mathrm{N} 137^{\circ} 53.060^{\prime} \mathrm{W}$, P. Caswell 03-555, 8 Aug. 2003 (DAO) (determined by S. J. Darbyshire).

The specimen cited above is a new introduction to the Yukon Territory but is not known to persist. It could not be found at this location in 2004. It is known across Canada from Quebec to southern British Columbia from dry fields and waste places.

Bromus japonicus can be described as follows: Annual, from fibrous roots. Culms (20-) $30-70 \mathrm{~cm}$ tall, erect or ascending; sheaths mostly very densely pilose to lanate, the upper ones sometimes pubescent to glabrous; ligules hairy; sheaths densely haired; blades $10-20 \mathrm{~cm}$ long, mostly softly pilose on both sides; panicle 10-17 (-22) cm long, diffuse nodding, with spreading to ascending, to somewhat drooping, slender, flexuous branchlets that are mostly longer than the spikelets; spikelets 6-12 flowered, glumes glabrous to scabrous, lanceolate, the lower one 3-nerved 4-6 $\mathrm{mm}$ long, the upper 5nerved 6-8.5 mm long; anthers included in the lemmas 1$1.5 \mathrm{~mm}$ long. It can be separated from Bromus hordeaceus as follows:

A. Panicle dense or narrow, usually erect; panicle branchlets and pedicels shorter

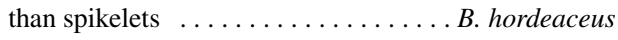

A. Panicle nodding or erect, mostly open; panicle branches and pedicels as long as or longer than spikelets ............. B. japonicus

Festuca brachyphylla Schultes \& Schultes f., Alpine Fescue - YukON: Kluane National Park, nunatak between Lowell and Dusty Glaciers near Ulu Mountain, $60^{\circ} 21^{\prime} 32^{\prime \prime N} 138^{\circ} 34^{\prime} 49^{\prime \prime W}$, B. A. Bennett 03-948, 6 July 2003 (DAO) (determined by S. J. Darbyshire).

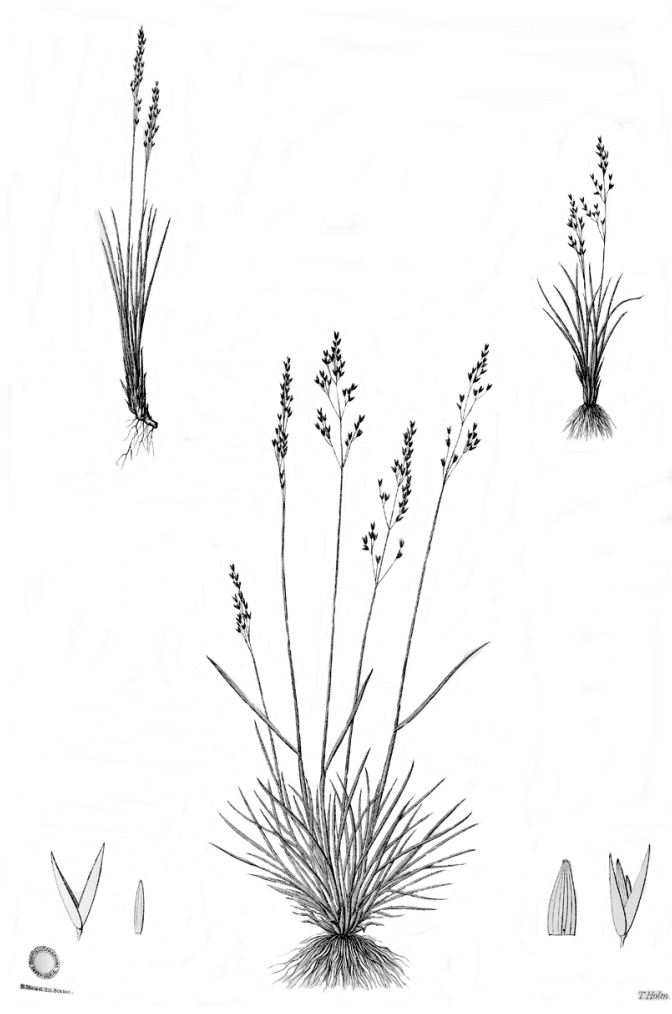

FIgURE 3. Agrostis humilis Vasey, Mountain Bent Grass (from Vasey, 1893. Grasses of the Pacific Slope)

The specimen cited above is an extension of the known range in the Park of about 50 kilometers south of a site mapped by Cody (1996).

Festuca brevissima Jurtz., Alaska Fescue - YUKON: Kluane National Park, loose rocks with some organic soil on rocky slope, Kings Throne Trail, $60^{\circ} 33.476 \mathrm{~N}$ $139^{\circ} 14.282^{\prime} \mathrm{W}$, P. Caswell 02-125, 21 June 2002 (DAO).

The specimen cited above of this Amphi-Beringian species is an extension of the known range in the Territory of about 350 kilometers south of a site about latitude $63^{\circ} 40^{\prime} \mathrm{N}$. It is new to the flora of Kluane National Park.

Festuca minutiflora Rydb., Little Fescue - YukON: Kluane National Park, loose soil with organic component at entrance of Arctic Ground Squirrel burrow, hill overlooking Ogilvie Glacier at termination of stream flowing south of Warden Cabin, nunatak at Logan Warden Cabin, $60^{\circ} 47.652^{\prime} \mathrm{N} 140^{\circ} 46.303^{\prime} \mathrm{W}$, P. Caswell et al. 03-334, 12 July 2003 (DAO).

The specimen cited above is the westernmost yet found in Kluane National Park and is an extension of the known range in the Park of about 100 kilometers to the west of a site mapped by Cody (1996).

Leymus mollis (Trin.) Pilger ssp. mollis s.l., American Lyme Grass - YukON: roadside gravel, Takhini Hotsprings Road about $1 \mathrm{~km}$ east of hotsprings, one 
patch only - introduced, $60^{\circ} 50^{\prime} 30^{\prime \prime} \mathrm{N} 135^{\circ} 20^{\prime} 30^{\prime \prime} \mathrm{W}$, B. A. Bennett, R. Elven \& H. Solstad 03-1300, 26 Aug. 2003 (DAO).

Cody (1996) knew ssp. villosissimus (Scribn.) A. Löve from adjacent to the Arctic coast. The specimen cited above is the first record of this variable subspecies from the interior and southern part of the Territory.

Phalaris arundinacea L., Reed Canary Grass - Yukon: $3 \mathrm{~km}$ west of White River along Alaska Highway on north side of road; appears to be seeded, $61^{\circ} 59^{\prime} \mathrm{N}$ $140^{\circ} 30^{\prime} 10^{\prime \prime} \mathrm{W}$, B. A. Bennett 04-0002, 10 April 2004 (DAO).

The specimen cited above is from a site about 225 kilometers northwest of a site southwest of Haines Junction in Kluane National Park cited by Cody et al. (2003) where it was native and a site about 175 kilometers to the northeast by Mechanic Creek where it was introduced (Cody et al. 2001).

Phippsia algida (Sol.) R.Br., Ice Grass - YuKon: Kluane National Park; dried and cracked mud at edge of large pond near Warden Cabin, nunatuk at Logan Warden Cabin, $60^{\circ} 47.628^{\prime} \mathrm{N} 140^{\circ} 45.148^{\prime} \mathrm{W}$, P. Caswell et al. 03-216, 11 July 2003 (DAO).

The specimen cited above, which is the most southwesterly yet found in the Territory, is from a site about 115 kilometers southwest of a site mapped by Cody (1996) near the south end of Kluane Lake.

Psathyrostachys juncea (Fisch.) Nevski (Elymus junceus Fisch.) Russian Wild Rye - YUKON: roadside at milepost 812, Alaska Highway, S. E. Welsh \& G. Moore 7635, 2 July 1968 (University of Alaska Herbarium, photo DAO) (determined by M. Barkworth). Stanley Welsh (1974) reported the specimen cited above and another one collected by M. V. Guttman collected from adjacent to Mile 1019 Alaska Hwy. on 25 July 1960 (ISC). These records were unfortunately missed when writing the Yukon Flora (Cody 1996, 2000).

This introduced species was first reported and described by Cody et al. (2003) sub. Elymus junceus from Dezadeash Lake adjacent to Km 195 Haines Hwy.

Secale cereale L., Rye - YukON: disturbed sandy soil, Whitehorse, between Mt. McIntyre Recreation Centre and Aquatic Centre Parking Lot, $60^{\circ} 03.32$ 'N $135^{\circ} 43.49^{\prime} \mathrm{W}$, B. A. Bennett 03-1369, 8 Oct. 2003 (B. A. Bennett Herbarium, photo DAO).

This introduced species was first collected by J. M. Gillett in gravel areas near warehouses in Watson Lake in 1949. The specimen cited above is only the second found growing wild in the Territory.

\section{CyPeRACEAE}

Blysmopsis rufa (Huds.) Oteng-Yeboah (Scirpus rufus (Huds.) Schrad., Blysmus rufus (Huds.) Link), Red Bulrush, Swaying Rush (Figure 5) - YUKON: alkaline lake, saline flat $600 \mathrm{~m}$ south of Fox Creek, on east side of North Klondike Hwy., Km 227, 61 ${ }^{\circ} 05.477$ 'N $135^{\circ} 16.826^{\prime} \mathrm{W}, \mathrm{R}$. Elven \& H. Solstad 03-1305, 25 Sept. 2003 (B. A. Bennett Herbarium, photo DAO).

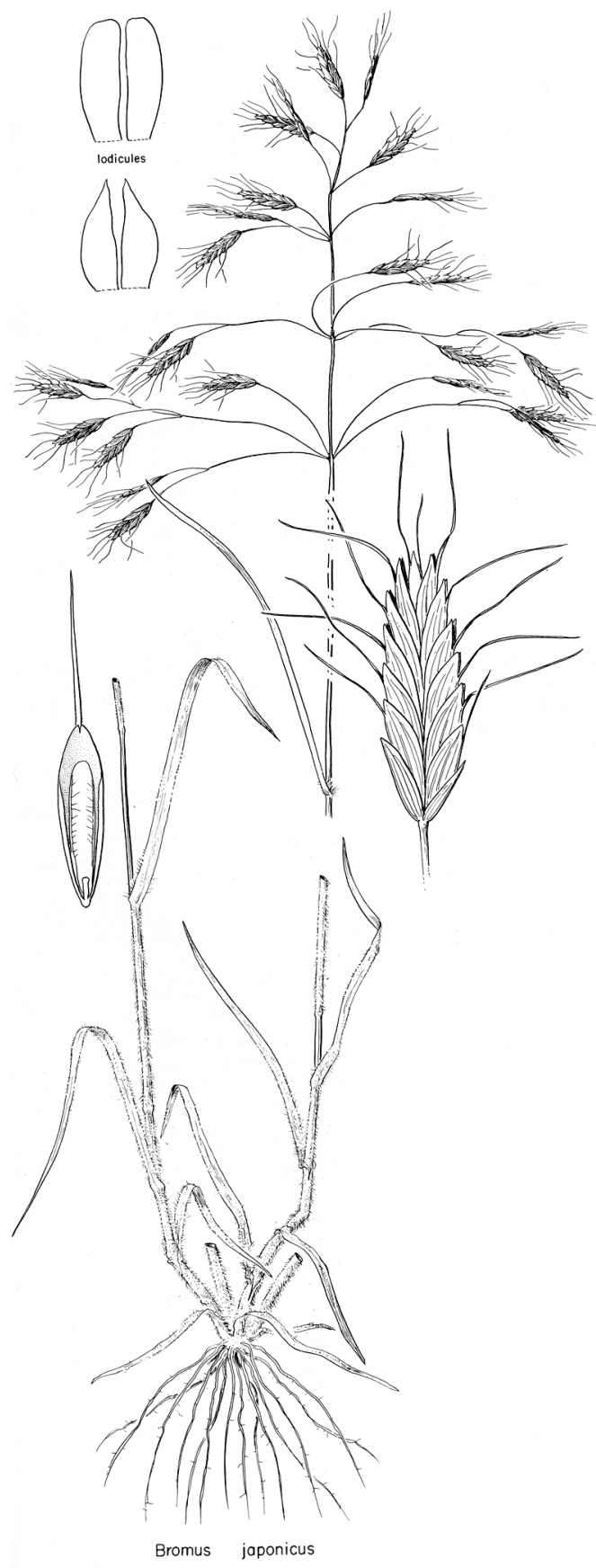

FIGURE 4. Bromus japonicus (Willd.) Rostk. \& Schmidt, Wavy Water Nymph (Japanese Brome) (illustration by J. R. Janish courtesy of the University of Washington Press). 
This is a new species to the flora of the Yukon Territory which should be added to the list of rare plants (Douglas et al. 1981). To the east it is rare in the former District of Mackenzie from a saline meadow adjacent to the Keele River in the Mackenzie Mountains and on saline river banks near Wrigley in the Mackenzie Valley and to the west from tidal flats in the Matanuska area. It can be separated from Schoenplectus tabernaemontani (Scirpus validus) as follows:

A. Spikelets several, 2-ranked, in a terminal spike; perianth bristles lacking,

inflorescence flattened .......... Blysmopsis rufa (Scirpus rufus)

A. Spikelets solitary or few to numerous, not 2-ranked, in compact to open umbels or panicles; inflorescences not flattened ......... Schoenplectus tabernaemontani (Scirpus validus)

Blysmopsis rufa (Scirpus rufus) can be described as: Perennial, loosely caespitose with horizontal rhizomes 1-3 mm thick; culms (5-) 10-45 cm $\times 1$ 1-2 (3) mm, glabrous; leaves 1-3; blades 2-12 (-18) $\mathrm{cm} \times 1.5-4 \mathrm{~mm}$, midrib inconspicuous, apex blunt, glabrous; inflorescence in loose spikes, 5-8 spikelets distichous, spreading-ascending; bracts erect to oblique, leaflike or scalelike, 4-15 mm; perianth bristles separating from achene when mature; style as long as stigma.

Carex bebbii (L. H. Bailey) Olney ex Fern., Bebb's Sedge (Figure 6) - YuKON: on old road to wetland west of bridge, north of road, La Biche River, $60^{\circ} 05.74$ 'N $124^{\circ} 01.98^{\prime} \mathrm{W}$, B. A. Bennett 98-634, 15 June 1998 (DAO) (determined by A. A. Reznicek).

This species is new to the flora of the Yukon Territory and should be added to the list of rare species (Douglas et al. 1981). In the present key Carex bebbii would key out as C. crawfordii, but can be distinguished from that species using the following characters:

A. Perigynia subulate to narrowly ovate-

lanceolate, 3-4 times as long as wide,

thin and scale-like ............ crawfordii

A. Perigynia narrowly to broadly ovate,

at most twice as long as wide,

membranous

C. bebbii

Carex brunnescens (Pers.) Poir., Brownish Sedge YUKON: Kluane National Park, very wet, muddy soil at base of beaver dam, trail between Mush Lake and Bates Lake, $60^{\circ} 18.047^{\prime} \mathrm{N} 137^{\circ} 31.560^{\prime} \mathrm{W}$, P. Caswell 03-699, 30 July 2003 (DAO).

The specimen cited above is an extension of the known range in the Park of about 40 kilometers south of a site at $60^{\circ} 42^{\prime} \mathrm{N} 137^{\circ} 27^{\prime} \mathrm{W}$ reported by Cody et al. (2003). These two sites are about 200 kilometers west of a site adjacent to Jake's Corner (Cody 1996).

Carex buxbaumii Wahlenb., Buxbaum's Sedge YUKON: bog with tussocks at edge of Haines Hwy., $60^{\circ} 08.570^{\prime} \mathrm{N} 136^{\circ} 58.469^{\prime} \mathrm{W}, P$. Caswell 02-454, 13 July 2002 (DAO); Kluane National Park, bank of shady streamlet shaded by willows, Auriol Trail, 64 $44^{\prime} 15^{\prime \prime} \mathrm{N}$ 137³0'40"W, P. Caswell 02-662, 7 Aug. 2002 (DAO); growing in edge of small thermokarst pond southwest of highway, Alaska Hwy., $6 \mathrm{~km}$ northwest of Dry Creek \#2, $62^{\circ} 13.455^{\prime} \mathrm{N} 140^{\circ} 41.544^{\prime} \mathrm{W}$, B. A. Bennett, R. Elven \& H. Solstad 03-087, 8 Aug. 2003 (DAO).

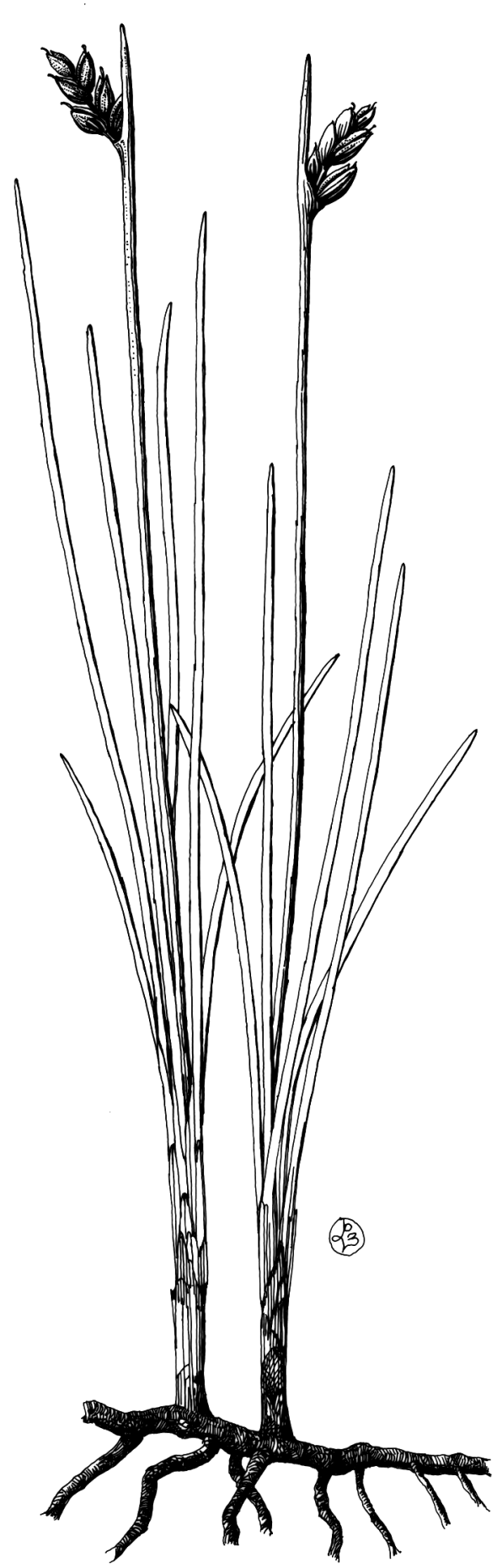

FIgURE 5. Blysmopsis rufa (Huds.) Oteng-Yeboah, Red Bulrush (drawn by Lee Mennell). 
This species was not included in the rare plants of the Territory (Douglas et al. 1981) because it is widespread circumpolar. The first specimen cited above is from a site about 125 kilometers southwest of Whitehorse. The second specimen is from a site just southwest of Haines Junction and is the second record for Kluane National Park. The third specimen is an extension of about 120 kilometers northwest of a site north of Kluane Lake.

Carex canescens L., Grey Sedge - YukON: Kluane National Park, Cyclops Lake, about $10 \mathrm{~km}$ NE of Mush Lake, 60²1'20"N 137 $11^{\prime} 30^{\prime \prime} \mathrm{W}$, R. D. Wickstrom 276, 21 July 1974 (DAO); gravel with some organic soil, base of highway embankment, streamlet west of Alaska Hwy. near Rock Glacier, $60^{\circ} 25.0^{\prime} \mathrm{N} 137^{\circ} 02.5^{\prime} \mathrm{W}$, P. Caswell 02-654, 5 Aug. 2002 (DAO).

This species is widespread throughout much of the Yukon Territory. The specimens cited above are new to Kluane National Park. The nearest site known to Cody (1996) is south of Whitehorse, about 125 kilometers to the east.

Carex eburnea Boott, Bristle-leaved Sedge - YuKON: growing in crevice of rockface, steep scree slope, old

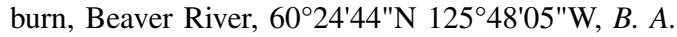
Bennett 97-456, 14 Aug. 1997 (DAO); dry scree below outcrop, Beaver River Camp \#1, 60³0'40"N 12606'26"W, B. A. Bennett 97-417, 13 Aug. 1997 (DAO); raven nest site, riverbar, base of cliff, Wind River, $65^{\circ} 12.49^{\prime} \mathrm{N} 135^{\circ} 13.17^{\prime} \mathrm{W}$, B. A. Bennett 00 369 , 5 July 2000 (DAO); silty seep on edge of river,

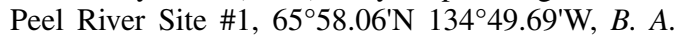
Bennett 00-433, 10 July 2000 (DAO) (determined by A. A. Reznicek); in floodplain tall closed balsam poplar, White River, $63^{\circ} 07.01^{\prime} \mathrm{N} 140^{\circ} 23.27^{\prime} \mathrm{W}, R$. Rosie s.n., 26 Aug. 2002 (B. A. Bennett Herbarium, photo DAO); Dempster Highway, Windy Pass, Km 160, flat floodplain with Leymus innovatus in sandy calcareous soil, Bennett \& Mulder 03-1307, 30 Aug. 2003 (DAO).

Douglas et al. (1981) knew this rare species in the Territory from a single collection in the Koidern area in the extreme west just south of latitude $62^{\circ} \mathrm{N}$. The first four specimens cited above which were originally determined as Carex capillaris and $C$. williamsii extend the known range to the extreme southeast and northeast to the Wind and Peel rivers. The additional two specimens extend the known range westward to the Dempster Highway and White River.

Carex lasiocarpa Ehrh., Slender Sedge - Yukon: flooded shoreline, Blind Lake, $60^{\circ} 05^{\prime} 0.5^{\prime \prime} \mathrm{N} 128^{\circ}$ 14'49.7"W, J. Staniforth 6, 26-28 June 2003 (DAO) (determined by P. M. Catling); small pond near highway northwest of bridge, mineralized soil, northwest side of Donjek River, $61^{\circ} 40.8^{\prime} \mathrm{N} 139^{\circ} 45.58^{\prime} \mathrm{W}, B$. A. Bennett, R. Elven \& H. Solstad 03-056, 8 Aug. 2003 (DAO).

This species was considered rare in the Territory (Douglas et al. 1981) on the basis of a collection from the Elsa area. An additional site was mapped in the southwest by Cody (1996). Cody et al. (1998, 2002) reported new sites in the southeast from the vicinities of Watson Lake and Frances Lake. The first specimen cited above is an extension of the known range of about 30 kilometers east of Watson Lake. The second specimen is an extension of the known range of

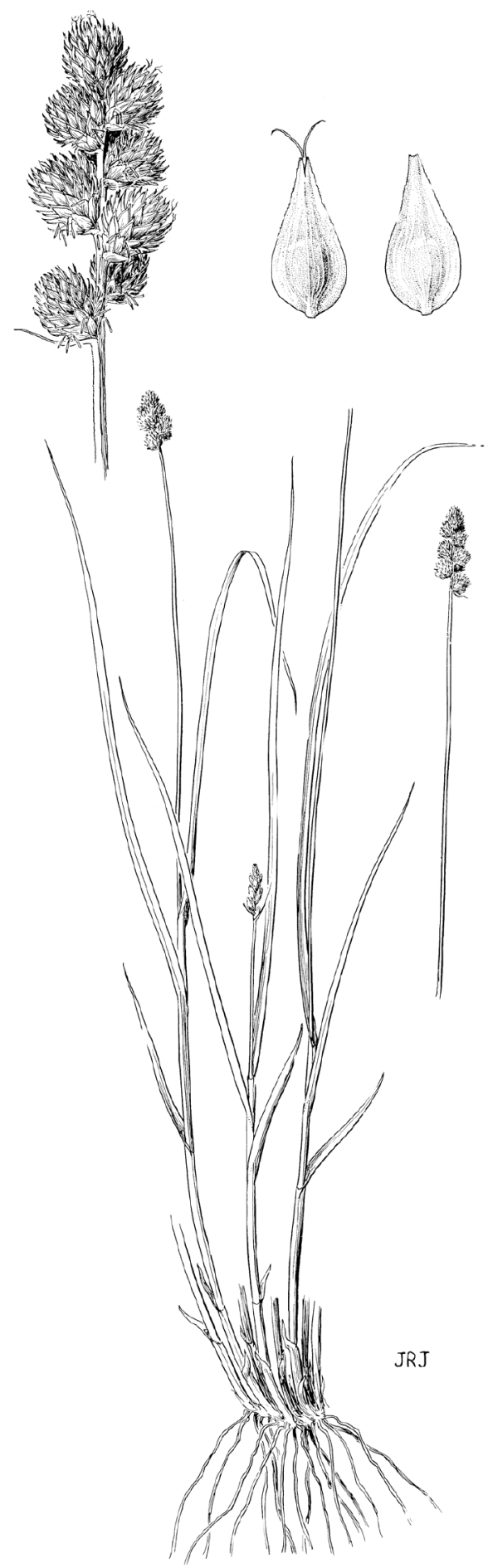

FIgURE 6. Carex bebbii (L.H. Bailey) Olney ex Fern., Bebb's Sedge (illustration by J. R. Janish courtesy of the University of Washington Press). 
about 60 kilometers north of a site in northern Kluane National Park.

Carex laxa Wahlenb., Weak Sedge - YuKON: edge of small thermokarst pond southwest of Alaska Highway 6 kilometers northwest of Dry Creek, $62^{\circ} 13.455^{\prime} \mathrm{N}$ $140^{\circ} 41.544^{\prime} \mathrm{W}$, B. A. Bennett, R. Elven \& H. Solstad 03-042, 8 Aug. 2003 (Yukon Government Herbarium, photo DAO).

This Amphi-Beringian species was previously known in North America from two stations in Alaska, one in the Mackenzie Delta, and two localities in Central Yukon where it was considered rare by Douglas et al. (1981) [Cody 1996]. The specimen cited above is from a site about 300 kilometers southwest of sites in the vicinities of Mayo and Elsa.

Carex lenticularis Michaux var. dolia (M. E. Jones) L. A. Standley (C. enanderi Hultén), Enander's Sedge - YukON: Kluane National Park, rare, seen only along creek near camp, Fisher Glacier near Alsek River, base camp, $60^{\circ} 08^{\prime} 31^{\prime \prime N} 138^{\circ} 13^{\prime} 13^{\prime \prime W}$, B. A. Bennett 03-955, 6 July 2003 (DAO) (determined by Ph.D. candidate Julie A. Dragon from the University of Vermont).

First reported from Yukon by Standley et al. (2002) this is a new variety in the Yukon Territory and should be added to the Rare Vascular Plants of the Yukon (Douglas et al. 1981). It can be separated from Carex lenticularis var. lenticularis as follows (from Flora of North America Volume 23):

A. Terminal spike gynecandrous (with pistillate flowers at the apex);

proximal spike not exceeding $1.5 \mathrm{~cm}$;

peduncle less than $1 \mathrm{~cm}$; perigynia

ovoid $\ldots \ldots \ldots \ldots \ldots \ldots \ldots \ldots \ldots$ var. dolia

A. Terminal spike usually staminate;

proximal spike longer than $1.5 \mathrm{~cm}$;

peduncle $1 \mathrm{~cm}$ or longer; perigynia

ovoid to ellipsoid ............. var. lenticularis

Carex eleusinoides is similar in inflorescence morphology, but may be distinguished by its red basal sheaths and short, veinless perigynia.

This species was considered rare in the Territory by Douglas et al. (1981). The specimen cited above, which is very reduced in size, is new to Kluane National Park and is from a site about 140 kilometers south of a site at the north end of Kluane Lake.

Carex lenticularis Michx. var. lipocarpa (Holm) L. A. Standley, Kellogg's Sedge - YuKON: Kluane National Park, braided river bed in muddy area toward a small pond, Plug Creek, 6003.593'N 138 $12.055^{\prime} \mathrm{W}$, P. Caswell et al. 03-672, 29 July 2003 (DAO).

Cody (1996) suggested that this sedge should be looked for in southern Yukon Territory because Hultén (1968) indicated collection sites from just north of where the British Columbia specimens were found. Bruce A. Bennett found it in a Sphagnum bog southeast of Watson Lake in 1996 (Cody et al. 1998). This record was overlooked by Standley et al. (2002). The specimen cited above is only the second yet confirmed and is from a site about 500 kilometers to the west.

Carex livida (Wahl.) Willd., Pale Sedge - YukON: southwest of highway, growing in edge of small thermokarst pond, Alaska Hwy., $6 \mathrm{~km} \mathrm{NW}$ of Dry Creek \#2, $62^{\circ} 13.455^{\prime} \mathrm{N} 140^{\circ} 41.555^{\prime} \mathrm{W}$, B. A. Bennett 03-043,

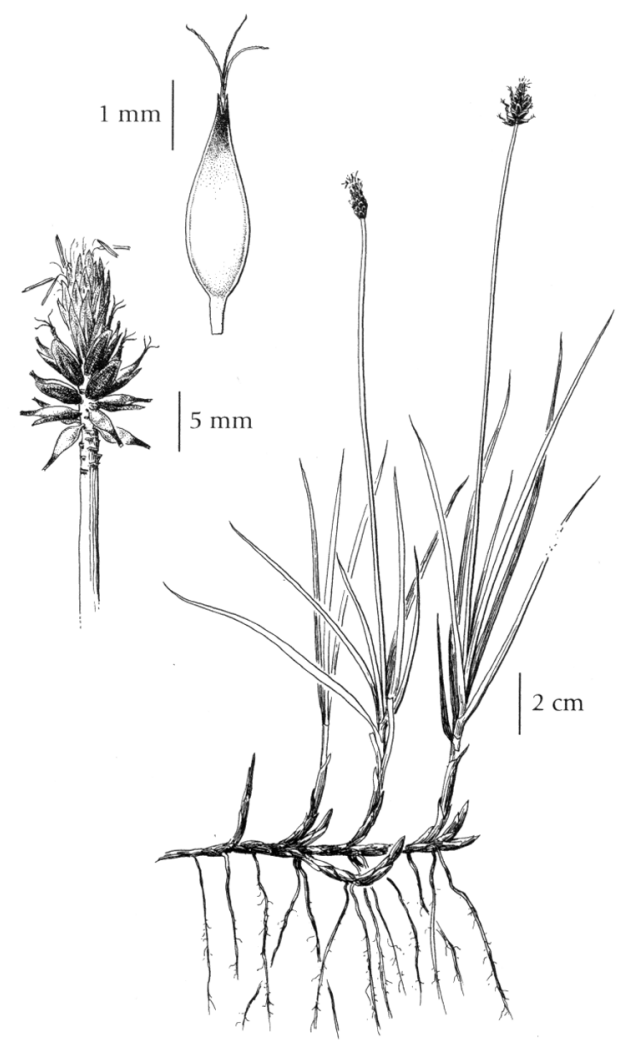

FIGURE 7. Carex nigricans C.A. Mey., Blackish Sedge. (illustration by J. R. Janish courtesy of the University of Washington Press).

8 Aug. 2003 (DAO); moist organic soil, bog east of Haines Hwy., 6008.421'N 136 $58.499^{\prime} \mathrm{W}$, P. Caswell 02-448, 13 July 2002 (DAO).

This circumpolar species with large gaps in its range was considered rare in the Territory by Douglas et al. (1981). The first specimen cited above is an extension of the known range in the Territory of about 160 kilometers west of a site southwest of Carmacks. The second specimen is from a site about 200 kilometers south of the site southwest of Carmacks.

Carex microglochin Wahl., Few-seeded Fen Sedge YUKON: moist organic soil in bog east of Haines Hwy., $60^{\circ} 08.421^{\prime} \mathrm{N} 136^{\circ} 59.499^{\prime} \mathrm{W}, P$. Caswell 02-452B, 13 July 2002 (DAO).

This circumpolar species was known to Cody (1996) from four widely separated areas in the Territory. The specimen cited above is from a site about 85 kilometers southeast of a site in Kluane National Park just southwest of Haines Junction.

Carex microptera Mack., Small-winged Sedge YuKON: wet lakeshore, Inlet of Caribou Creek to Caribou Lake, $60^{\circ} 32.0^{\prime} \mathrm{N} 134^{\circ} 15.9^{\prime} \mathrm{W}$, S. Withers SWOO168, 7 Aug. 2000 (DAO).

This collection originally identified as Carex pachystachya (Cody et al. 2003) was reidentified by A. A. Reznicek. Douglas et al. (1981) did not consider this species rare in the 
Territory because it is widespread in western North America. Cody (1996) knew it from only nine sites in the southern part of the Territory. The specimen cited above is from a site intermediate between the vicinities of Whitehorse and Johnson's Crossing.

Carex nardina Fries, Spikehead Sedge - YuKON: Kluane National Park, nunatak near Ulu Mountain, $60^{\circ} 21^{\prime} 32^{\prime \prime N} 138^{\circ} 34^{\prime} 49^{\prime \prime W}$, B. A. Bennett 03-929, 6 July 2003 (DAO).

The specimen cited above is an extension of the known range in the Park of about 35 kilometers southwest of the most southeasterly site in the Park mapped by Cody (1996).

Carex nigricans C. A. Mey., Blackish Sedge (Figure 7) - YuKON: Kluane National Park, uncommon, seen along creek near camp and muddy flats upstream, Fisher Glacier near Alsek River, base camp, 6008'31"N $138^{\circ} 13^{\prime} 13^{\prime \prime W}$, B. A. Bennett 03-954, 6 July 2003 (DAO); $300 \mathrm{~m}$ east of camp, flat moist tundra at bottom of broad valley with Diphasiastrum alpinum, Juncus drummondii, Fisher Glacier near Alsek River, 60 $08^{\prime} 31^{\prime \prime} \mathrm{N}$ 138 13'13"W, B. A. Bennett 03-1074, 8 July 2003 (DAO).

This is a new species in the Yukon Territory and should be added to The Rare Vascular Plants of the Yukon (Douglas et al. 1981). Carex nigricans can be described as: plants loosely caespitose, mat-forming; rhizomes short, stout; culms 5-30 cm; leaves flat to the tip, 2-4 mm wide; pistillate scales reddish brown to black, lanceolate, as broad as long and as long as or slightly longer than perigynia, margins not hyaline or scarious, apex acute to acuminate; perigynia 3.8-4.1 $\times 1-1.2 \mathrm{~mm}$; beak dark brown to black, frequently as long as body of perigynium; stigmas 3 . It can be separated from Carex pyrenaica as follows:

A. Plants rhizomatous; leaves $1.5-2 \mathrm{~mm}$

broad, flat or channelled basally;

staminate flowers occupying one-third

to one-half of the spike .......... nigricans

A. Plants clump-forming; leaves $1.5 \mathrm{~mm}$

broad or less, channelled throughout;

staminate flowers occupying less than

one-third of the spike ............ pyrenaica

Carex parryana Dewey, Parry's Sedge - YUKON: silty broad alkaline river flat, northwest side of Donjek River, $61^{\circ} 40.8^{\prime} \mathrm{N} 139^{\circ} 45.58^{\prime} \mathrm{W}$, B. A. Bennett, R. Elven \& H. Solstad 03-054, 8 Aug. 2003 (DAO).

The specimen cited above is an extension of the known range in the Territory (Cody 1996) of about 125 kilometers northwest of a site in the vicinity of Kluane Lake.

Carex phaeocephala Piper, Dunhead Sedge - YuKON: Kluane National Park, west-facing slope, drier soils in herbaceous meadow dominated by Luetkea pectinata, Fisher Glacier near Alsek River, 6008'09"N $138^{\circ} 13^{\prime} 10^{\prime \prime W}$, B. A. Bennett 03-986, 7 July 2003 (DAO); common open herbaceous and graminoid meadow of south-facing mid-slopes in drier patches of open soil, northeast of base camp, Fisher Glacier near Alsek River, 6008'31"N 138 $13^{\prime} 13^{\prime \prime W}$, B. A. Bennett 031065, 8 July 2003 (DAO) (determined by A. A. Reznicek); south-facing slope, thin coarse soil surround- ed by boulders and ice, nunatak between Lowell and Dusty glaciers near Ulu Mountain, 60²1'32"N 138 34'49"W, B. A. Bennett 03-930, 6 July 2003 (DAO) (determined by A. A. Reznicek).

Douglas et al. (1981) knew this rare species in the Territory only from Kluane National Park. The first two specimens cited above are an extension of about 70 kilometers west of a site adjacent to the Haines Hwy. mapped by Cody (1996) and the third specimen is about 40 kilometers further to the northwest.

Carex sartwellii Dewey, Sartwell's Sedge (Figure 8) - YUKON: occasional in alkaline area in grassy openings on dwarf birch-willow flats at 2500', Mile 26 on road from Whitehorse to Dawson, $61^{\circ} 08^{\prime} \mathrm{N} 135^{\circ} 21^{\prime} \mathrm{W}$, J. A. Calder and I. Kukkonen 28035, 9 Aug. 1960 (DAO) (determined by A. A. Reznicek).

This is a new species to be found in the Yukon Territory and should be added to the list of rare species (Douglas et al. 1981). It can be separated from Carex praegracilis as follows:

A. Upper sheaths translucent below; perigynia with beaks not sharply

bidentate, not thin - margined

above .................. praegracilis

A. Upper sheaths green-lined below;

perigynia with beaks sharply

bidentate, thin margined above .......C. sartwellii

In Canada this species is known from south-central and southeastern British Columbia north to southern part of the former District of Mackenzie and east to Quebec. Carex sartwellii can be described as follows: Perennial herb from stout, creeping, scaly, fibre-covered rhizomes; stems $30-80 \mathrm{~cm}$ tall arising singly or a few together, longer than the leaves; sheaths tight, brown, glabrous, inner band green; blades 2-4 per stem 2.5-5 mm wide, lower ones reduced to scales; spikes 20 or more nearly cylindrical, except near the apex; basal spikes more prominent than middle spikes; perigynia (2.3-) 2.8-4 × 1.3-2 mm; achenes brown, smooth 1.2-2 mm long, stigmas 2 .

Carex siccata Dewey, Hay Sedge - Yukon: Picea mariana dominated forest, Beaver River near Larsen Airstrip, $60^{\circ} 10^{\prime} 42^{\prime \prime N} 125^{\circ} 05^{\prime} 38^{\prime \prime} \mathrm{W}$, B. A. Bennett 95314, 22 June 1995 (B. A. Bennett Herbarium, photo DAO) (determined by A. A. Reznicek).

The specimen cited above was originally identified as Carex foenea (Cody et al. 1998) and all of the three specimens mapped previously (Cody 1996) are presumably referable to this species. The name Carex foenea correctly refers to a species in section Ovales $(C$. aenea), but has frequently been misapplied to this species. Carex foenea $(=C$. aenea of Cody 1996) is widespread in southern Yukon. The name Carex siccata was first applied to Yukon plants by Reznicek (2002). Carex foenea and C. siccata can be separated as follows:

A. Plants caespitose; spikes 3-7 (-11);

perigynia with wing $0.2-0.4 \mathrm{~mm}$ wide $\ldots$ Carex foenea

A. Plant with long creeping rhizomes;

spikes 4-12; perigynia wingless ..... Carex siccata

Eriophorum gracile Koch, Slender Cotton-grass YUKON: flooded shoreline, Blind Lake, $60^{\circ} 05^{\prime} 0.5^{\prime \prime} \mathrm{N}$ $128^{\circ} 14^{\prime} 49.7^{\prime \prime W}$, J. Staniforth 3, 26-28 June 2003 (DAO). 
Cody (1994) reported the first specimen known from the Territory from a site near the British Columbia border between longitudes $127^{\circ} \mathrm{W}$ and $128^{\circ} \mathrm{W}$ and recommended that this species should be added to the list of rare vascular plants of the Yukon Territory (Douglas et al. 1981). Additional specimens have since been reported from Upper Coal River and Frances Lake (Cody et al. 1998) and Turner Lake (Cody et al. 2001). The specimen cited above is from a site about half way between the first known site and Watson Lake.

Schoenoplectus acutus (Muhl. ex Bigelow) A. \& D. Löve var. acutus) (Scirpus acutus Muhl. ex Bigelow), Hard-stemmed Bulrush - YUKON: aquatic emergent, Blind Lake, 6006'7.9"N 128 13'1.6"W, J. Staniforth 7, 26-28 June 2003 (DAO).

The specimen cited above is an extension of the known range in the Territory of about 300 kilometers southeast of sites in the vicinity of Ross River (Cody et al. 2001).

Schoenoplectus tabernaemontani (C.C. Gmel.) Palla (Scirpus validus Vahl), Soft-stem Club-rush - YUKON: extensively placer mined area, Lower Hunker Creek area east of Dawson City, 6401'14.2"N 13909'01.2"W, G. Brunner 593, 7 Sept. 2003 (DAO).

The specimen cited above is from a site about 150 kilometers south of a site adjacent to the Dempster Hwy. and about 175 kilometers northwest of a site in the vicinity of Mayo.

Trichophorum alpinum (L.) Pers. (Scirpus hudsonianus (Michx.) Fern.), Hudson Bay Clubrush - YuKON: growing in edge of small thermokarst pond southwest of Alaska Hwy., $6 \mathrm{~km} \mathrm{NW}$ of Dry Creek \#2, $62^{\circ} 13.455^{\prime} \mathrm{N} 140^{\circ} 41.544^{\prime} \mathrm{W}$, B. A. Bennett, R. Elven \& H. Solstad 03-044, 8 Aug. 2003 (DAO).

The specimen cited above is an extension of the known range in the Territory of about 50 kilometers to the northwest of a site adjacent to the Alaska Hwy. mapped by Cody (1996).

\section{JUNCACEAE}

Juncus bufonius L. s.1., Toad Rush - YUKON: in shallows of northeast shore with Callitriche and Eleocharis, Hidden Lakes, Whitehorse, 6041.9'N 13500.6'W, B. A. Bennett 03-070, 13 Aug. 2003 (DAO); Kluane National Park, packed moist sand with small rocks and organic component, strip in middle of road, Alsek Trail, $60^{\circ} 46.042^{\prime} \mathrm{N} 137^{\circ} 44.657^{\prime} \mathrm{W}$, P. Caswell 03-755, 25 Aug. 2003 (DAO).

The first specimen cited above is from a site in the southern part of the Territory between sites in the vicinities of Haines Junction and east of South Canol Road. The second specimen is an extension of the known range in the Territory of about 250 kilometers southwest of a site south of Mayo mapped by Cody (1996).

Juncus filiformis L., Thread Rush - YuKON: Kluane National Park, wet, muddy soil, small marsh at lakeshore, west end of Mush Lake, $60^{\circ} 18.377 \mathrm{~N} 137^{\circ}$ 32.681'W, P. Caswell 03-687, 30 July 2003 (DAO).

The specimen cited above is an extension of the known range in the Territory of about 85 kilometers southwest of a site adjacent to the Alaska Hwy. east of Haines Junction

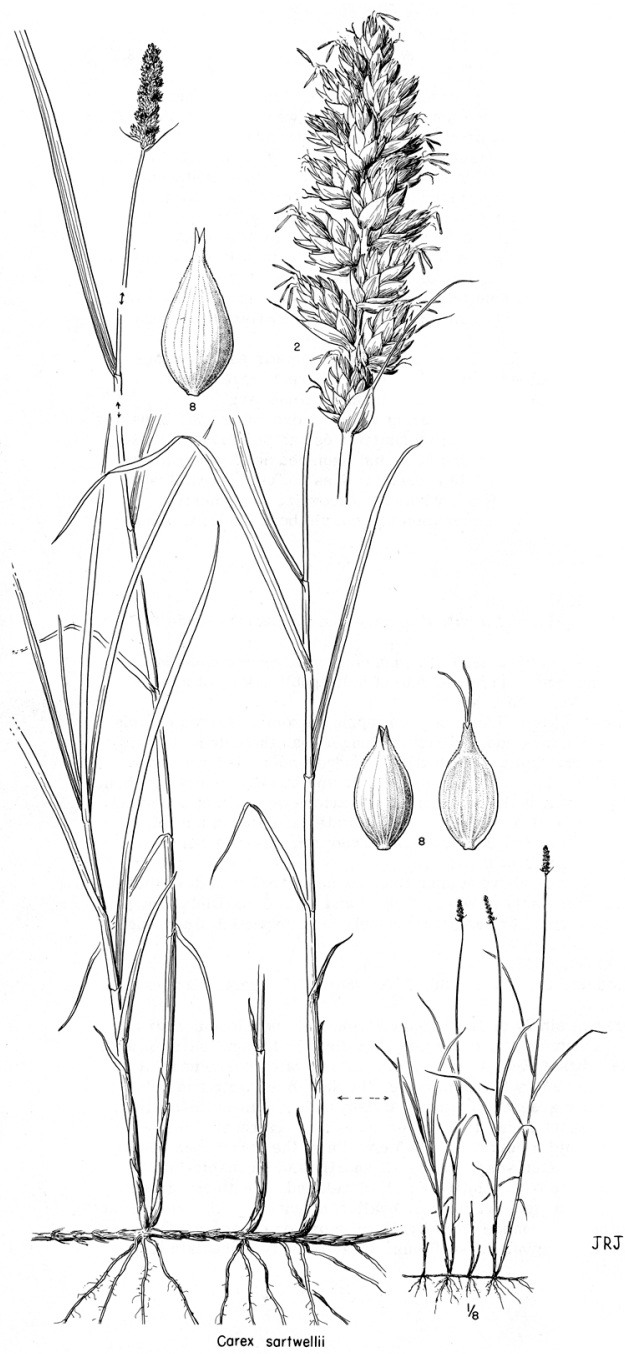

FIGURE 8. Carex sartwellii Dewey, Sartwell's Sedge. (illustration by J. R. Janish courtesy of the University of Washington Press).

reported by Cody et al. (2004). It is new to Kluane National Park.

Luzula piperi (Cov.) M. E. Jones, Piper's Wood-rush - YUKON: Kluane National Park, uncommon in herbaceous meadows, usually on the toe of slopes, Fisher

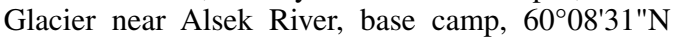
$138^{\circ} 13^{\prime} 13^{\prime \prime W}$, B. A. Bennett 03-972, 6 July 2003 (DAO).

The specimen cited above is only the third known to Cody (1996) in Kluane National Park. It is an extension of the known range to the southwest of about 40 kilometers.

Luzula spicata (L.) DC., Spiked Wood-rush - YUKON: Kluane National Park, W-facing slope above valley 
glacier leading into Fisher Glacier near Alsek River, $60^{\circ} 08^{\prime} 25^{\prime \prime N} 138^{\circ} 13^{\prime} 20^{\prime \prime W}$, B. A. Bennett 03-1016, 7 July 2003 (DAO).

The specimen cited above is the southernmost yet found in the Park. It is about 40 kilometers south-southwest of a site southwest of Haines Junction.

\section{LILIACEAE}

Triantha glutinosa (Michx.) Baker (Tofieldia glutinosa ssp. brevistyla sensu Cody (1996)), Sticky False Asphodel - YUKON: silty broad alkaline river on flat, seasonally flooding shore, dominated by Salix brachycarpa, Carex parryana, Calamagrostis stricta and Aster yukonensis, northwest side of Donjek River, $61^{\circ} 40.8^{\prime} \mathrm{N}$ $139^{\circ} 45.58^{\prime} \mathrm{W}$, B. A. Bennett, R. Elven \& H. Solstad 03-050, 8 Aug. 2003 (DAO).

Douglas et al. (1981) considered this taxon as rare in the Territory. The specimen cited above is an extension of the known range of about 230 kilometers northwest of a site in the vicinity of Whitehorse where it was collected by C. E. Kennedy et al. in 1996. The scientific name Triantha glutinosa was brought forward by Douglas et al. (2001) and Utech (2002).

\section{IRIDACIAE}

Iris setosa Pall. ssp. interior (Anders.) Hultén - YUKON: southwest of highway, growing in edge of small thermokarst pond, Alaska Hwy. $6 \mathrm{~km}$ NW of Dry Creek $\# 2,62^{\circ} 13.455^{\prime} \mathrm{N} 140^{\circ} 41.544^{\prime} \mathrm{W}, B$. A. Bennett, $R$. Elven \& H. Solstad 03-048, 8 Aug. 2003 (B. A. Bennett Herbarium, photo DAO).

This species was considered rare in the Territory by Douglas et al. (1981). The specimen cited above is from a site about 20 kilometers southeast of the Alaska border.

\section{ORCHIDACEAE}

Coeloglossum viride (L.) Hartm. ssp. bracteatum (Muhl. ex Willd.) Hultén, Bracted Green Orchid YUKON: moist, black organic soil, edge of road shaded by poplar woods, old road west of Alaska Hwy. (between Kluane Wilderness Camp (Scully's bar) and Donjek River), $61^{\circ} 36.701^{\prime} \mathrm{N} 139^{\circ} 37.730^{\prime} \mathrm{W}$, P. Caswell 02-189, 25 June 2002 (DAO).

Douglas et al. (1981) considered this species rare in the Territory on the basis of a single collection in the extreme south in the vicinity of Little Atlin Lake. Cody (1996) added a second site from adjacent to the Bonnet Plume River at latitude $65^{\circ} 10^{\prime} \mathrm{N}$, and Cody et al. (2001/2002) added two additional sites east and west of the Bonnet Plume River site and a site near the Donjek River. The specimen cited above is an extension of the known range in the Territory of about 13 kilometers southeast of the Donjek River site.

\section{SALICACEAE}

Salix niphoclada Rydb. (S. brachycarpa Nutt. ssp. niphoclada (Rydb.) Argus, Barren-ground Willow YUKON: Kluane National Park, Fisher Glacier near Alsek River, SW-facing above glacier, $60^{\circ} 08^{\prime} 06 " \mathrm{~N}$ $138^{\circ} 12^{\prime} 42^{\prime \prime W}$, B. A. Bennett 03-1027, 7 July 2003 (DAO) (determined by G. W. Argus).

The specimen cited above is the southernmost yet found in Kluane National Park.

\section{SANTALACEAE}

Comandra umbellata (L.) Nutt. ssp. pallida (A.DC.) Piehl, Pale Commandra - YukON: Kluane National Park, open, sage-covered sweeping slope overlooking Slims West Trail and west of the Sheep Bullion Trail, $60^{\circ} 59.138^{\prime} \mathrm{N} 138^{\circ} 35.832^{\prime} \mathrm{W}, P$. Caswell \& $L$. Freese 03-753, 3 Aug. 2003 (DAO).

The specimen cited above is the first known of this species from Kluane National Park. It was however known to Cody (1996) from adjacent to Kluane Lake on the east side of the Alaska Hwy. Cody (1996) also mapped a site near the Five Finger Rapids adjacent to the Klondike Hwy. southeast of Fort Selkirk (F. Anderson, 18 June 1898, Hultén 1940). It has not been seen again in that area despite some searching. Hultén (1968) and Douglas et al. (1981) accidentally mapped it from the vicinity of Dawson.

\section{POLYGONACEAE}

Polygonum achoreum Blake, Striate Knotweed YUKON: front yard of cabin, Lee's Camp, Beaver River, $60^{\circ} 11^{\prime} 57^{\prime \prime N} 125^{\circ} 09^{\prime} 42^{\prime \prime} \mathrm{W}$, B. A. Bennett 97-493, 18 Aug. 1997 (DAO) (determined by M. Costea).

The specimen cited above, originally identified as $P$. buxiforme (Cody et al. 2000), is an extension of the known range in the Territory of about 575 kilometers east of the vicinity of Whitehorse.

Polygonum convolvulus L., Bind-weed, Wild Buckwheat - YUKON: dry, very rich organic soil, abandoned vegetable garden, 14 Willow Acres, Haines Junction, $60^{\circ} 45.823^{\prime} \mathrm{N} 137^{\circ} 29.458^{\prime} \mathrm{W}$, P. Caswell 03-427, 17 July 2003 (DAO).

Cody (1996) knew this introduced species in the Territory from only four widely separated sites (Whitehorse, Dawson, Carmacks and adjacent to the Campbell Highway northwest of Ross River).

Polygonum lapathifolium L. (P. pensylvanicum L. ssp. oneillii (Brenckle) Hultén - YUKON: usually submerged in shallow water in marly mud, Ear Lake, Whitehorse, $60^{\circ} 40.81^{\prime} \mathrm{N} 135^{\circ} 02.54^{\prime} \mathrm{W}$, B. A. Bennett 03-035, 9 Aug. 2003 (DAO); in shallows of northeast shore with Callitriche verna and Eleocharis acicularis, Hidden Lake, Whitehorse, $60^{\circ} 41.9^{\prime} \mathrm{N} 135^{\circ} 00.6^{\prime} \mathrm{W}$, B. A. Bennett 03-071, 13 Aug. 2003 (DAO).

Cody et al. (2000) reported this species, which was considered rare in the Territory by Douglas et al. (1981), from three sites about 100 kilometers northwest of the specimens cited above.

Polygonum persicaria L., Lady's-thumb - Cody (1996, 2000) reported the occurrence of this species based on a collection from the Canol Road Mile 55-60 on the east shore of Quiet Lake near Old Road Camp by A. E. Porsild \& A. J. Breitung 11124, 4 July 1944 (CAN).

This specimen was reviewed by R. Staniforth (1975) who reported that it was possibly P. lapathifolium. It was reviewed again by L. L. Consaul (1987) who revised it to P. lapathifolium. P. persicaria should be deleted from the flora of the Yukon Territory. 
Rumex maritimus L. ssp. fueginus (Phil.) Hultén, Golden Dock - Yukon: dry, very rich organic soil, abandoned vegetable garden at 14 Willow Acres, Haines Junction, $60^{\circ} 45.823^{\prime} \mathrm{N} \quad 137^{\circ} 29.458^{\prime} \mathrm{W}, \quad P$. Caswell 03-437, 17 July 2003 (DAO) (determined by S. J. Darbyshire).

The specimen cited above is an extension of about 35 kilometers southeast of a site adjacent to the Alaska Hwy. mapped by Cody (1996).

\section{CARYOPHYLLACEAE}

Minuartia dawsonensis (Britt.) House, Bog Sandwort - Yukon: Kluane National Park, packed earth on trail, Alsek Trail past Serpentine Creek, $60^{\circ} 41.397 ' \mathrm{~N}$ $137^{\circ} 46.603^{\prime} \mathrm{W}$, P. Caswell 02-220, 26 June 2002 (DAO).

The specimen cited above is the first reported from Kluane National Park. It is from a site about 30 kilometers southeast of a site mapped by Cody (1996) adjacent to the Alaska Hwy.

Sagina nivalis (Lindbl.) Fries - YukON: Kluane National Park, frost heaved mud beside large rocks at edge of lake, shore of pond, south side of large pond in front of Warden Cabin, nunatak at Logan Warden Cabin, $60^{\circ} 47.628^{\prime} \mathrm{N} 140^{\circ} 45.148^{\prime} \mathrm{W}, P$. Caswell et al. 03-356, 3 July 2003 (DAO).

The specimen cited above is only the second record of the occurrence of this rare species in Kluane National Park where it is about 175 kilometers northwest of the first site (Cody 1996). Douglas et al. (1981) considered this species rare in the Yukon Territory.

Silene acaulis (L.) Jacq. ssp. subacaulescens (F.N. Williams) Hultén - YUKON: Kluane National Park, Fisher Glacier near Alsek River, base camp, 60 $00^{\circ} 31 " \mathrm{~N}$ $138^{\circ} 13^{\prime} 13 " \mathrm{~W}$, B. A. Bennett 03-965, 6 July 2003 (DAO).

The specimen cited above is only the second known from the Park. To the north the nearest sites are just south of latitude $64^{\circ} \mathrm{N}$ and to the east just east of longitude $133^{\circ} \mathrm{W}$ (Cody 1996).

Stellaria umbellata Turcz., Umbellate Starwort YUKON: Buckland Hills, Ivvavik National Park, $69^{\circ} 25^{\prime} \mathrm{N} 139^{\circ} 38^{\prime} \mathrm{W}, R$. Elven 7229-99, 5 Aug. 1999 (University of Alaska Herbarium, photo DAO) (determined by R. Elven).

This species was considered rare in the Territory by Douglas et al. (1981). Cody (1996) knew it from only three widely separated sites. The specimen cited above is an extension of the known range of about 60 kilometers to the northwest of a site adjacent to the Babbage River.

\section{NyMPHAEACEAE}

Nuphar variegatum Engelm., Bullhead Lily - YUKON: pond south of the Alaska Hwy. and west of Donjek River, $61^{\circ} 41^{\prime} 11.8^{\prime \prime N} 139^{\circ} 47^{\prime} 01.6 " \mathrm{~W}$, D. Normandeau 03-533, 26 July 2003 (DAO).

This is a rare species in the Territory (Douglas et al. 1981). The specimen cited above is an extension of the known range of about 230 kilometers southwest of a site south of Mayo mapped by Cody (1996).

\section{RANUNCULACEAE}

Clematis occidentalis (Hornem.) DC. ssp. grosseserrata (Rydb.) Taylor \& MacBryde, Purple Clematis YUKON: Haines Junction, L. Fournier s.n., 13 July 1958 (QFA).

The sample of Clematis was revised by B. Boivin in 1965 to $C$. tangutica, with the note: "Note many folioles, more likely to be $C$. tangutica, maybe cultivated." Clematis tangutica is a species that has escaped from cultivation and persists in the vicinity of Whitehorse and Carcross (Cody et al. 2001). Clematis occidentalis should be deleted from the flora of the Yukon Territory.

\section{PAPAVERACEAE}

Papaver radicatum Rottb. ssp. kluanensis (D. Löve) D. F. Murray - Yukon: alpine, Friday Creek, $60^{\circ} 25^{\prime} \mathrm{N}$ 135²1'W, A. Rhodes 99-537, 11 Aug. 1999 (B. A. Bennett Herbarium, photo DAO) (determined by R. Elvin and H. Solstad).

The specimen cited above is an extension of about 120 kilometers east of the type site in Kluane National Park (Murray 1995).

\section{BRASSICACEAE}

Aphragmus eschscholtzianus Andrz., Eschscholtz' Little Nightmare, Aleutian Cress - YUKON: Kluane National Park, moist, frost sorted rocks and gravel, Wade Mountain, $61^{\circ} 18.594^{\prime} \mathrm{N} 139^{\circ} 30.921^{\prime} \mathrm{W}$, P. Caswell 02-353, 7 July 2002 (DAO) (determined by G. A. Mulligan).

Douglas et al. (1981) knew this rare species in the Territory from only four sites in the southwest, three of which were in Kluane National Park. The specimen cited above is the fourth in the Park and is from a site about 45 kilometers east of the westernmost site mapped by Cody (1996).

Arabidopsis salsuginea (Pallas) N. Busch (Thellungiella salsuginea (Pallas) O. E. Schulz), Saltwater Cress - YUKON: very rich organic soil, abandoned Llama pasture, Haines Junction, 14 Willow Circle, $60^{\circ} 45.816^{\prime} \mathrm{N}$ $137^{\circ} 29.466^{\prime} \mathrm{W}, P$. Caswell $03-414$, 17 July 2003 ; same area, $60^{\circ} 45.843^{\prime} \mathrm{N} 137^{\circ} 24.484^{\prime} \mathrm{W}$, P. Caswell 03-055, 19 June 2003 (DAO) (determined by G. A. Mulligan).

Douglas et al. (1981) and Cody (1996) knew this species from only five sites in the southwest of the Territory. The sixth site cited above is from a location just southeast of the westernmost previously recorded.

Arabis boivinii G. A. Mulligan - YuKON: Kluane National Park, dry sand with organic component, Mush Lake Warden Cabin at west end of Mush Lake, $60^{\circ} 18.4966^{\prime} \mathrm{N} 137^{\circ} 32.776^{\prime} \mathrm{W}$, P. Caswell 03-708, 31 July 2003 (DAO) (determined by G. A. Mulligan).

Cody et al. (2001) reported the first two known sites in the Territory from adjacent to the Haines Hwy. Cody et al. (2003) reported a third site from the old Experimental Farm northwest of Haines Junction. The specimen cited above is the first known from within the borders of Kluane National Park.

Draba albertina Greene, Slender Draba, Alaska Whitlow-grass - YUKON: Kluane National Park, roadside 
spruce forest, Alaska Hwy. at squirrel research area, $60^{\circ} 57.226^{\prime} \mathrm{N} 138^{\circ} 02.466^{\prime} \mathrm{W}$, P. Caswell 03-037, 12 June 2003 (DAO); dry organic soil, middle of road, abandoned road from Dalton Post to Wade Lakes, $60^{\circ} 06.192$ 'N $137^{\circ} 07.847^{\prime} \mathrm{W}$, P. Caswell 24, 6 June 2002 (DAO) (determined by G. A. Mulligan).

The first specimen cited above is from a site intermediate between two areas in the Park mapped by Cody (1996). The second specimen is the most southerly yet found in the Park about 30 kilometers south of a site reported in Cody et al. (2003).

Draba cinerea J. E. Adams, Gray-leaved Whitlowgrass - YUKON: Kluane National Park, moist organic soil on hill above an alpine marsh, nunatak at Logan Warden Cabin, $60^{\circ} 47.598^{\prime} \mathrm{N} 140^{\circ} 45.588^{\prime} \mathrm{W}$, P. Caswell et al. 03-328A, 12 July 2003 (DAO) (determined by G. A. Mulligan).

The specimen cited above is the most southwesterly yet found in the Territory. It is from a site about 50 kilometers south of a site at about latitude $61^{\circ} 10^{\prime} \mathrm{N}$ (Cody 1996).

Draba crassifolia Grah., Rocky Mountain Whitlowgrass - YUKON: Kluane National Park, organic soil among large rocks, old lake bed, nunatak at Logan Warden Cabin, $60^{\circ} 47.500^{\prime} \mathrm{N} 140^{\circ} 44.991^{\prime} \mathrm{W}$, P. Caswell, R. Maraj \& L. Fries 03-291, 12 July 2003 (DAO) (determined by G. A. Mulligan).

The specimen cited above is an extension of the known range in the Park of about 80 kilometers west of two sites mapped by Cody (1996) and is the westernmost yet known in that area.

Draba lonchocarpa Rydb. var. vestita O. E. Schulz, Alaska Whitlow-grass - YUKON: Kluane National Park, rocks and gravel, Cache Lake, $61^{\circ} 12.454$ 'N $139^{\circ} 03.757^{\prime} \mathrm{W}$, P. Caswell 60B, 12 June 2002 (DAO) (determined by G. A. Mulligan); Kluane National Park, glacial till with thin organic cover, nunatak at Logan Warden Cabin, $60^{\circ} 47.628^{\prime} \mathrm{N} 140^{\circ} 45.148^{\prime} \mathrm{W}$, P. Caswell et al. 03-351, 12 July 2003 (DAO) (determined by G. A. Mulligan).

Cody et al. (2001) reported the first record of this rare variety in the Territory from the extreme southeast. The specimens cited above extend the known range in the Territory about 1000 kilometers to the west to near the Alaska border.

Draba nivalis Liljebl., Snow Draba - YUKON: Kluane National Park, moist organic soil on hill above an alpine marsh, nunatak at Logan Warden Cabin, $60^{\circ} 47.598^{\prime} \mathrm{N} 140^{\circ} 45.588^{\prime} \mathrm{W}$, P. Caswell et al. $03-$ 328A-B, 12 July 2003 (DAO) (determined by G. A. Mulligan).

The specimen cited above is the most southwesterly yet found in the Territory. It is from a site about 100 kilometers west of a site at about 138 $30^{\prime} \mathrm{W}$ (Cody 1996).

Draba oligosperma Hook., Few-seeded Draba, Fewseeded Whitlow-grass - YUKON: scree slope, dry rocky soil with little humus, abandoned road between Dalton Post and Wade Lakes, $60^{\circ} 05.992^{\prime} \mathrm{N} 137^{\circ} 08.531^{\prime} \mathrm{W}$,
P. Caswell 02-25, 6 June 2002 (DAO) (determined by G. A. Mulligan).

The specimen cited above which is the southernmost yet found in Kluane National Park is an extension of the known range in the Territory of about 75 kilometers southeast of a site southwest of Haines Junction.

Draba scotteri G. A. Mulligan - YUKON: Kluane National Park, scree with organic soil, alpine tundra, nunatak at Logan Warden Camp, $60^{\circ} 46.958^{\prime} \mathrm{N} 140^{\circ}$ 44.864'W, P. Caswell et al. 284, 11 July 2003 (DAO); moist organic soil alpine tundra on hillside, nunatak at Logan Warden Cabin, $60^{\circ} 47.545^{\prime} \mathrm{N} 140^{\circ} 45.334^{\prime} \mathrm{W}$, P. Caswell et al. 03-176, 10 July 2003 (DAO) (determined by G. A. Mulligan).

This is a rare species in the Territory (Douglas et al. 1981). The specimens cited above are from sites about 120 kilometers west of sites mapped by Cody (1996) in Kluane National Park.

Draba stenoloba Ledeb., Alaska Draba - YukON: Kluane National Park, organic soil, right of way of abandoned pipeline, south of Auriol Trail, $60^{\circ} 42.932^{\prime} \mathrm{N}$ $137^{\circ} 25.565^{\prime} \mathrm{W}$, P. Caswell 03-70, 21 June 2003 (DAO) (determined by G. A. Mulligan).

The specimen cited above is from a site intermediate between sites mapped by Cody (1996) on the Haines and Alaska highways.

Draba stenopetala Trautv., Starflowered Whitlow-grass - YUKON: small quantity of inorganic soil between two rocks, barren mountain summit, mountain east of Haines Hwy. just north of British Columbia border, $60^{\circ} 03.115^{\prime} \mathrm{N} 136^{\circ} 50.004^{\prime} \mathrm{W}$, L. Struever s.n., 1 July 2003 (DAO) (determined by G. A. Mulligan).

Douglas et al. (1981) knew this rare species in the Territory from only three sites in Kluane National Park. Cody (1996) mapped two additional sites east of the Dempster Hwy. and Cody et al. (2001) added two additional sites in the south at longitudes $135^{\circ} 29^{\prime} \mathrm{W}$ and $134^{\circ} 41^{\prime} \mathrm{W}$. The specimen cited above is from a site about 30 kilometers east of the nearest site in southern Kluane National Park.

\section{DROSERACEAE}

Drosera anglica Huds., Great Sundew - YuKON: growing at edge of small thermokarst pond, Alaska Hwy. $6 \mathrm{~km} \mathrm{NW}$ of Dry Creek \#2, 62 $13.455^{\prime} \mathrm{N} 140^{\circ}$ 41.544'W, B. A. Bennett, R. Elven \& H. Solstad 03-046, 8 Aug. 2003 (B. A. Bennett Herbarium, photo DAO).

This species was considered rare in the Territory by Douglas et al. (1981). The specimen cited above is from a site about 250 kilometers southwest of a site in the vicinity of Mayo (Cody 1996).

\section{SAXIFRAGACEAE}

Leptarrhena pyrolifolia (D.Don) R.Br. ex Ser., Leather-leaved Saxifrage - YUKON: Kluane National Park, Fisher Glacier near Alsek River, lower southfacing slope north of glacier, $60^{\circ} 08^{\prime} 31^{\prime \prime} \mathrm{N} 138^{\circ} 13^{\prime} 13^{\prime \prime} \mathrm{W}$, B. A. Bennett 03-978, 6 July 2003 (Yukon Government Herbarium, photo DAO). 
Cody (1996) knew this species in the Park from only two sites about halfway between this site and Haines Junction. The nearest other site was about 300 kilometers to the northeast adjacent to the South Canol Road.

Parnassia fimbriata Koenig, Fringed Grass-of-Parnassus - YUKON: Kluane National Park, Fisher Glacier near Alsek River, NE of base camp, common in open herbaceous and graminoid meadows of southfacing lower slopes north of camp, $60^{\circ} 08^{\prime} 31^{\prime \prime} \mathrm{N} 138^{\circ}$ 13'13"W, B. A. Bennett 03-1066, 8 July 2003 (DAO).

The specimen cited above is the southernmost yet found in the Park. It is about 50 kilometers southeast and southwest of the only two other sites mapped by Cody (1996) in the Park.

Saxifraga nelsoniana D.Don ssp. carlottae (Calder \& Savile) Hultén (S. punctata L. ssp. carlottae Calder \& Savile) - YUKON: in wet sand and gravel by streamlet on south side of large pond at Long Warden Cabin, nunatak, $60^{\circ} 47.628^{\prime} \mathrm{N} 140^{\circ} 45.148^{\prime} \mathrm{W}$, P. Caswell et al. 03-368, 13 July 2003 (DAO).

The specimen cited above fits this subspecies which is new to the Yukon Territory (Cody 1996) on the basis of the scarcely cordate leaves with less than 12 lobes. It is, however, in flower and lacks the long, narrow, deeply cleft capsules. The following information is provided from Calder and Savile (1960): "Subspecies carlottae is abundant on moist alpine or subalpine slopes or clefts in the Queen Charlotte Islands; but it has also spread to the mainland where it intergrades freely with ssp. pacifica and ssp. porsildiana. ... Attention must be drawn to the plants in the Prince William Sound region of southern Alaska, cited as intermediate between ssp. carlottae and ssp. pacifica. These plants are actually closer in morphology to carlottae than pacifica, despite the occurrence of pure pacifica further east."

Saxifraga nelsoniana D.Don ssp. pacifica (Hultén) Hultén (Saxifraga punctata L. ssp. pacifica Hultén) YuKON: Kluane National Park, Fisher Glacier near Alsek River, W-facing slope above valley glacier, $60^{\circ} 08^{\prime} 25^{\prime \prime N} 138^{\circ} 13 ' 20^{\prime \prime W}$, B. A. Bennett 03-1001, 7 July 2003 (DAO).

The specimen cited above is the most southwesterly yet found in the Park. It is from a site about 75 kilometers west of a site adjacent to the Haines Highway.

Saxifraga rufopilosa (Hultén) A. E. Porsild - YUKON: Kluane National Park, Fisher Glacier near Alsek River, W-facing slope above valley glacier, 6008'20"N 138 13'20"W, B. A. Bennett 03-996, 7 July 2003 (DAO).

The specimen cited above is the southernmost yet found in the Park. It is from a site about 60 kilometers south of a site mapped by Cody (1996) southwest of Haines Junction.

\section{ROSACEAE}

Dryas integrifolia Vahl ssp. crenulata (Juz.) J. Kozhevn (D. crenulata Juz.) - YUKON: Kluane National Park, Fisher Glacier near Alsek River, base camp, common on south and west-facing slopes and occasionally on upper slopes and in valley, 6008'31"N 138 $13^{\circ} 13^{\prime \prime} \mathrm{W}$, B. A. Bennett 03-978, 6 July 2003 (B. A. Bennett Herbarium, photo DAO).
The specimen cited above is the southernmost yet found in the Park. It is from a site about 100 kilometers south of a site mapped by Cody (1996) southeast of Kluane Lake.

Dryas octopetala L. ssp. hookeriana (Juz.) Hultén (D. hookeriana Juz.) - YUKON: Kluane National Park, Fisher Glacier near Alsek base camp, common on south- and west-facing slopes, 60 $08^{\prime} 31^{\prime \prime} \mathrm{N} 138^{\circ} 13^{\prime} 13^{\prime \prime} \mathrm{W}$, B. A. Bennett 03-1085, 6 July 2003 (B. A. Bennett Herbarium, photo DAO).

The specimen cited above is the southernmost yet known in the Park. It is about 30 kilometers south of a site southwest of Haines Junction mapped by Cody (1996).

Luetkea pectinata (Pursh) Kuntze, Partridge-foot YuKON: Kluane National Park, Fisher Glacier near Alsek River, west-facing slope above valley glacier leading into Fisher Glacier, 6008'16"N 138 $13^{\circ} 28^{\prime \prime} \mathrm{W}$, B. A. Bennett 03-988, 7 July 2003 (Yukon Government Herbarium, photo DAO).

This species was known to Cody (1996) from only two sites in the southeast of the Park. The specimen cited above is an extension of the known range in the Park of about 25 kilometers west of the southernmost site.

Potentilla bipinnatifida Dougl. ex Hook., Bipinnate Cinquefoil - YUKON: Kluane National Park, packed earth and gravel with organic component, centre of road, Alsek Trail, P. Caswell 02-437, 12 July 2002 (DAO).

Cody (1996) stated that this species was apparently rare in northern and southwestern parts of the Territory but it was not included in The Rare Vascular Plants of the Yukon Territory (Douglas et al. 1981). The specimen cited above is from a site intermittent between two sites mapped by Cody in the Park.

Rosa woodsii Lindl., Western Rose - YukON: Pelly Crossing, growing on upper south-facing $45^{\circ}$ bluff slope, 62 49'57"N 136 34'45"W, B. A. Bennett 03095, 1 Sept. 2003 (DAO).

The specimen cited above is an extension of about 90 kilometers north of Carmacks.

Sorbus sitchensis Roemer - YUKON: Kluane National Park, Fisher Glacier near Alsek River, NE of base camp, only a single plant seen in open herbaceous and graminoid meadows of south-facing lower mid-slope growing 1.5 meters tall, $60^{\circ} 08^{\prime} 31^{\prime \prime} \mathrm{N} 138^{\circ} 13^{\prime} 13^{\prime \prime} \mathrm{W}$, B. A. Bennett 03-1071, 8 July 2003 (DAO).

This species which was considered rare in the Territory by Douglas et al. (1981) was known to Cody (1996) from only two nearby sites in the extreme south of Kluane National Park. The specimen cited above is an extension of the known range in the Territory of about 25 kilometers to the west.

\section{LEGUMINOSAE (FABACEAE)}

Astragalus alpinus L., Alpine Milk-vetch - YUKON: Kluane National Park, nunatak between Lowell and Dusty glaciers, near Ulu Mountain, 60²1'32"N $138^{\circ}$ 34'49"W, B. A. Bennett 03-941, 6 July 2003 (DAO).

The specimen cited above is from the most southwesterly site in the Park. This site is about 25 kilometers west of a site mapped by Cody (1996). 
Lupinus nootkatensis Donn ex Sims, Nootka Lupine - YUKON: Kluane National Park, Fisher Glacier near Alsek River, slope above valley glacier leading into the glacier, $60^{\circ} 08^{\prime} 16^{\prime \prime} \mathrm{N} 138^{\circ} 28^{\prime} \mathrm{W}$, B. A. Bennett 03 1006, 7 July 2003 (Yukon Government Herbarium, photo DAO).

The specimen cited above is an extension of the known range in the Park of about 25 kilometers southwest of this rare species in the Territory (Douglas et al. 1981) which was known to Cody (1996) from only two sites in the extreme south and an additional site adjacent to the Haines Highway (Cody et al. 2004).

Oxytropis arctica R.Br. var. arctica, Arctic Oxytrope - YUKON: Vuntut National Park, ca. 13 miles W of Sam Lake, $68.35^{\circ} \mathrm{N} 139.1667^{\circ} \mathrm{W}$, S. L. Welsh 10340 , 9 July 1970 (ALA).

Cody (1996) described and keyed this species, which is known from arctic Canada and northern Alaska, and suggested that it should be looked for in the mountains of northern Yukon Territory. It should be added to the list of rare plants in the Territory (Douglas et al. 1981).

Oxytropis arctica R.Br. var. murrayi (Yurtzev) S. Welsh (O. sordida [Willd.] Pers. ssp. murrayi B. A. Yurtsev), Murray's Oxytrope - YUKON: Kluane National Park, Observation Mtn. and vicinity at terminus of Kaskawulsh Glacier, $60.8167^{\circ} \mathrm{N} 138.7334^{\circ} \mathrm{W}, D$. F and B. Murray 522, 10 July 1966 (ALA); Kluane National Park, Fisher Glacier near Alsek River, west-facing $15^{\circ}$ slope, above valley glacier in Dryas integrifolia heath tundra with Hedysarum boreale, Senecio ogortorukensis, some limestone in the thin soil, just nearing ridge, $60^{\circ} 08^{\prime} 12^{\prime \prime} \mathrm{N} 138^{\circ} 13^{\prime} 14^{\prime \prime} \mathrm{W}$, B. A. Bennett 03-981, 7 July 2003 (DAO).

This plant was fairly common on this site but became less common quickly as you follow the ridge to the summit. This is a new variety first reported in Cody et al. (2004) in flora of the Yukon Territory, which is endemic to Kluane National Park. It should be added to the list of rare plants (Douglas et al. 1981). Oxytropis arctica var. murrayi can be separated from var. arctica as follows:

A. Leaves seldom with some leaflets fasciculate; leaflets often over $8 \mathrm{~mm}$ long, at least some, plants of arctic in $\mathrm{N}$ Yukon $\ldots \ldots \ldots \ldots \ldots$............ var. arctica

A. Leaves typically with fasciculate leaflets; leaflets mainly less than

$8 \mathrm{~mm}$ long; plants of SW Yukon ....... var. murrayi Oxytropis arctica var. murrayi can be described as follows: Plants mainly $4-16 \mathrm{~cm}$ tall. Leaves $3-12 \mathrm{~cm}$ long; leaflets 17-numerous, opposite, scattered or more typically fasciculate, mainly 3-8 $\mathrm{mm}$ long, but in some up to $14 \mathrm{~mm}$. Scapes 4-12 (14) cm; racemes 2-7 flowered, subcapitate or slightly elongate; calyx tube shaggy villous with light and dark hairs, 4-5 mm long. Pods 17-21 mm, spreading. Type: Yukon, St. Elias Mts., Observation Mt. and vicinity, at terminus of Kaskawulsh Glacier, D. F. \& B. M. Murray 522, 10 July 1966. Flowering in summer. Ridge crests, talus slopes, and meadows at $725-1830 \mathrm{~m}$.

Oxytropis campestris (L.) DC. ssp. jordalii (A. E. Porsild) Hultén, Jordal's Oxytrope - YUKON: Kluane National Park, Fisher Glacier near Alsek River, NE of base camp, drier open south-facing mid slope, $60^{\circ} 08^{\prime} 31^{\prime \prime N} 138^{\circ} 13^{\prime} 13 " \mathrm{~W}$, B. A. Bennett 03-1070, 8 July 2003 (DAO); west-facing slope $40^{\circ}-50^{\circ}$, above valley glacier leading into Fisher Glacier, $60^{\circ} 08^{\prime} 16^{\prime \prime} \mathrm{N}$ $138^{\circ} 13^{\prime} 28^{\prime \prime W}$, B. A. Bennett 03-992, 7 July 2003 (B. A. Bennett Herbarium, photo DAO).

The specimens cited above are the first reported from Kluane National Park and are an extension of the known range in the Territory of about 200 kilometers west of sites in the vicinity of Carcross (Cody 1996).

Oxytropis nigrescens (Pall.) Fisch. ssp. nigrescens, Blackish Locoweed - YUKON: Kluane National Park, Fisher Glacier near Alsek River, west-facing slope $40^{\circ}-50^{\circ}$ above valley glacier leading into Fisher Glacier, $60^{\circ} 08^{\prime} 16^{\prime \prime N} 138^{\circ} 13^{\prime} 28^{\prime \prime W}$, B. A. Bennett 03-991, 7 July 2003 (DAO).

The specimen cited above is an extension of the known range in the Park of about 75 kilometers south of a site mapped by Cody (1996) west of Haines Junction.

Vicia americana Muhl., American Vetch - YukON: behind cabins, north end of Dawson City by Whitehorse Cabins, $64^{\circ} 04^{\prime} \mathrm{N} 139^{\circ} 26^{\prime} \mathrm{W}$, G. Brunner 585, 12 Sept. 2003 (DAO).

The collection cited above is from a site about 175 kilometers west-northwest of Mayo and was undoubtedly introduced there.

\section{GeRANIACEAE}

Geranium erianthum DC., Northern Geranium YUKON: Kluane National Park, organic soil in meadow, Plug Creek, $60^{\circ} 03.593^{\prime} \mathrm{N} 138^{\circ} 12.055^{\prime} \mathrm{W}$, P. Caswell et al. 03-675, 29 July 2003 (DAO).

This is a rare species in the Territory (Douglas et al. 1981) where it is mainly found in Kluane National Park. The specimen cited above is the westernmost site adjacent to the British Columbia border.

\section{Violaceae}

Viola adunca J. E. Smith, Hook-spur Violet - YUKON: Kluane National Park, growing in shady areas under willows by small creek on west slope above valley glacier leading into Fisher Glacier near Alsek River, $60^{\circ} 08^{\prime} 10^{\prime \prime} \mathrm{N} 138^{\circ} 13^{\prime} 15^{\prime \prime} \mathrm{W}$, B. A. Bennett 03-985, 7 July 2003 (DAO).

The specimen cited above is an extension of the known range in the Park of about 35 kilometers northwest of a site mapped by Cody (1996) near the British Columbia border.

\section{ONAGRACEAE}

Epilobium hornemannii Reichenb. ssp. hornemannii, Hornemann's Willowherb - YUKON: Kluane National Park, dry wind-packed fine scree, nunatak north of Lowell Glacier, $60^{\circ} 18.297^{\prime} \mathrm{N} 138^{\circ} 34.503^{\prime} \mathrm{W}$, P. Caswell 03-604, 29 July 2003 (DAO).

The specimen cited above is an extension of the known range into southern Kluane National Park of about 100 kilometers southwest of a site east of Haines Junction (Cody 1996).

\section{HALORAGACEAE}

Myriophyllum verticillatum L., Verticillate Water-milfoil - YUKON: muddy substrate, in two feet of water, 
growing in dense clumps, Poison Lake, $60^{\circ} 14.6866^{\prime} \mathrm{N}$ $136^{\circ} 57.421^{\prime} \mathrm{W}$, P. Caswell 03-493, 24 July 2003 (DAO).

This is a rare species in the Territory (Douglas et al. 1981). The specimen cited above is an extension of the known range of about 80 kilometers southeast of a site northwest of Haines Junction (Cody 1996).

\section{APIACEAE}

Angelica lucida L., Seacoast Angelica - YUKON: Kluane National Park, moist, organic soil, Plug Creek, $60^{\circ} 03.593^{\prime} \mathrm{N} 138^{\circ} 12.055^{\prime} \mathrm{W}$, P. Caswell et al. 03-666, 29 July 2003 (DAO).

This is a rare species in the Yukon Territory (Douglas et al. 1981). The specimen cited above is the westernmost yet known in the Territory and is an extension of about 75 kilometers west of the Lower Alsek River in the extreme southeast of the Park (Douglas and Ruyle-Douglas 1978).

\section{ERICACEAE}

Harrimanella stellariana (Pallas) Coville (Cassiope stellariana (Pallas) DC.), Alaskan Mountain-heather - YUKON: Kluane National Park, abundant sometimes forming nearly pure stands covering areas in the lower valley and the lower north-facing slopes, Fisher Glacier near Alsek River, base camp, $60^{\circ} 08^{\prime} 31^{\prime \prime} \mathrm{N} 138^{\circ}$ 13'13"W, B. A. Bennett 03-953, 6 July 2003 (DAO).

This species was reported as rare in the Territory by Douglas et al. (1981) on the basis of only three known sites, two of which were in Kluane National Park. The specimen cited above is an extension of about 25 kilometers to the west in the Park.

Phyllodoce $\times$ intermedia (Hook.) Rydb. - YukON: Kluane National Park, Fisher Glacier near Alsek River, southwest-facing slope $30^{\circ}$ above Fisher Glacier, $60^{\circ} 08^{\prime} 06 " \mathrm{~N} 138^{\circ} 12^{\prime} 58^{\prime \prime} \mathrm{W}$, B. A. Bennett 03-1035, 7 July 2003 (B. A. Bennett Herbarium, photo DAO).

Cody et al. (2001) reported the first known occurrence of this hybrid between Phyllodoce empetriformis and P. glandulifera from a wooded site near Kathleen Lake at about Mile 140 Haines Road, about 75 kilometers northwest of the second site in Kluane National Park.

\section{PRIMUlaceAe}

Douglasia ochotensis (Willd.) Hultén, Arctic-Montane Dwarf-Primrose - YukON: Dempster Highway kilometer 440, 4 km southwest of Rock River Campground with Salix phlebophylla in platey loose shale slope, 66 52'37"N 136 19 '58"W, B. A. Bennett 03078, 13 Aug. 2003 (DAO).

The specimen cited above is the easternmost yet found in the Territory. It is from a site about 175 kilometers southeast of the nearest site mapped by Cody (1996).

Primula nutans Georgi (P. sibirica Jacq.), Siberian Primrose - YUKON: damp organic soil, uneven tundra, Alaska Hwy. at squirrel research area, $60^{\circ} 57.156^{\prime} \mathrm{N}$ $138^{\circ} 02.086 ' \mathrm{~W}$, P. Caswell 03-034, 12 June 2003 (DAO).

This Amphi-Beringian species is found in North America in extreme western Alaska and then disjunct to eastern Alaska and southwestern Yukon Territory (Hultén 1968). The specimen cited above is a slight extension to the northwest from sites in the Haines Junction region mapped by Cody (1996).

\section{GentianACEAE}

Swertia perennis L., Alpine Bog Swertia - Yukon: wet organic soil, open Picea glauca forest, second gully east of Haines Highway proceeding north from the British Columbia border, $60^{\circ} 00.403^{\prime} \mathrm{N} 136^{\circ} 51.061^{\prime} \mathrm{W}$, P. Caswell 03-546, 2 Aug. 2003 (DAO).

Cody (1996) suggested that this species was to be looked for in southwestern Yukon Territory. It has now been found and should be added to the list of rare plants in the Territory.

\section{MenYanthaceae}

Menyanthes trifoliata L., Buckbean, Bogbean - YukON: pond west of Alaska Hwy., north of Donjek bridge, $61^{\circ} 41^{\prime} 11.8^{\prime \prime N} 139^{\circ} 47^{\prime} 01.6^{\prime \prime} \mathrm{W}$, D. Normadeau s.n., 26 July 2003 (DAO); emergent in highway pond, $4 \mathrm{~km}$ SE of Pickhandle Lake, 61 ${ }^{\circ} 54^{\prime} 20^{\prime \prime N} 140^{\circ} 13^{\prime} 00^{\prime \prime} \mathrm{W}, B$. A. Bennett 97-27, 6 June 1996 (DAO); "Eagle Lake", $61^{\circ} 23^{\prime} 30^{\prime \prime} \mathrm{N} 139^{\circ} 41^{\prime} 30^{\prime \prime} \mathrm{W}$, R. D. Wickstrom s.n., 20 Aug. 1974 (DAO).

The three sites cited above extend the known range in the Territory about 115 kilometers southeast of a site adjacent to the Alaska Hwy. and Alaska border.

\section{APOCYNACEAE}

Apocynum androsaemifolium L., Spreading Dogbane - YUKON: in open dry Pinus contorta/lichen woods, Watson Lake area, $60^{\circ} 11^{\prime} \mathrm{N} 129^{\circ} 05^{\prime} \mathrm{W}, R$. Rosie 1893 , 6 July 1995 (DAO); open Pine/Lichen bluff above lake, Blind Lake, $60^{\circ} 04^{\prime} 43.3^{\prime \prime N} 128^{\circ} 15^{\prime} 3.7^{\prime \prime W}$, J. Staniforth 2, 26-28 June 2003 (DAO).

Cody (1996) knew this species as occasional north to the vicinity of Dawson City. The specimens cited above are from sites west of the easternmost mapped by Cody.

\section{Polemoniaceae}

Polemonium pulcherrimum Hook., Showy Jacob's Ladder - YUKON: Kluane National Park, nunatak between Lowell and Dusty glaciers near Ulu Mountain, on $35-40^{\circ}$ south-facing slope, $60^{\circ} 21^{\prime} 32^{\prime \prime} \mathrm{N} 138^{\circ}$ 34'49"W, B. A. Bennett 03-923, 6 July 2003 (DAO).

The specimen cited above is from a site intermediate between two sites in the extreme south of the Park about 125 kilometers apart.

\section{VERBENACEAE}

Verbena hastata L. - A specimen which was collected by Phil Caswell at Haines Junction on 13 August 2000 was identified to this species by B. A. Bennett and confirmed by W. J. Cody. It was reported as new to the Yukon Territory by Cody et al. (2003). Unfortunately this specimen was misidentified and has been correctly revised to Veronica longifolia L., by Stuart G. Hay of the Herbier Marie-Victorin (MT), Université de Montréal, a species which was first collected along the Alaska Hwy. by Cody and Ginns in July 1980. Verbena hastata should be deleted from the flora of the Yukon Territory.

\section{SCROPHULARIACEAE}

Castilleja miniata Dougl. ex Hook., Scarlet Paintbrush - YUKON: Kluane National Park, moist, organic soil, meadow on north shore of first lake from St. Elias Lake, Secret Lakes, $60^{\circ} 18.979^{\prime} \mathrm{N} 137^{\circ} 08.208^{\prime} \mathrm{W}, P$. Caswell \& L. Freese 03-524, 26 July 2003 (DAO). 
This species was considered rare in the Territory by Douglas et al. (1981) who knew it only east of Atlin Lake and the Larson Creek hot springs. Catherine Kennedy collected it at the Coal River Springs area in 1983 (Cody 1994) and Mark Egger collected it adjacent to the Top of the World Hwy. west of Dawson City in 1991 (Egger 1992). The specimen cited above is a new record for Kluane National Park, about 200 kilometers west of the site near Atlin Lake.

Castilleja parviflora Bong., Small-flowered Paintbrush - YUKON: Kluane National Park, scree with a small organic component, nunatak (abandoned weather station) north of Lowell Glacier, $60^{\circ} 18.297 ' \mathrm{~N}$ $138^{\circ} 34.503^{\prime} \mathrm{W}$, P. Caswell et al. 03-603, 29 July 2003 (DAO).

This rare plant in the Territory (Douglas et al. 1981) is only known in the Territory in the southeast of Kluane National Park. The specimen cited above is from a site about 75 kilometers northwest by west of the southernmost mapped by Cody (1996).

Castilleja unalaschcensis (Willd.) Hultén, Unalaska Paintbrush - YUKON: Kluane National Park, Fisher Glacier near Alsek River, southwest-facing $30^{\circ}$ slope above Fisher Glacier, $60^{\circ} 08^{\prime} 06^{\prime \prime} \mathrm{N} 138^{\circ} 12^{\prime} 58^{\prime \prime} \mathrm{W}, B$. A. Bennett 03-1021, 7 July 2003 (DAO).

The specimen cited above is an extension of the known range in the southern part of the Park of about 30 kilometers west of a site mapped by Cody (1996).

Veronica americana Schwein., American Brooklime - YuKOn: Haines Hwy., interface of dried mud and water, beaver pond on east side of highway about $10 \mathrm{~km}$ south of Kathleen Lake cutoff, $60^{\circ} 30.838^{\prime} \mathrm{N} 137^{\circ}$ 04.970'W, P. Caswell 02-788, 11 Aug. 2002 (DAO).

Cody (1996) reported this species as occasional in the Territory north to about latitude $63^{\circ} \mathrm{N}$. The specimen cited above is from a site about 80 kilometers southeast of the westernmost location in the Territory adjacent to the Alaska Hwy.

\section{OROBANCHACEAE}

Orobanche fasciculata Nutt., Clustered Broomrape YUKON: mid-slope, Conglomerate Mountain, $61.6252^{\circ} \mathrm{N}$ $135.8755^{\circ} \mathrm{W}$, B. A. Bennett \& S. Thompson 03-011, 2 May 2003 (DAO); old esker complex with silty soil, gravel and boulders at crest of south-facing slope, Haunka Creek, 60²1'05.4"N 133 53'29.3"W, B. A. Bennett, R. \& P. Mulder 04-0052, 22 May 2004 (DAO).

Douglas et al. (1981) considered this species rare in the Territory. The first specimen cited above is from a site intermediate between Carmacks and a site just north of Whitehorse (Cody 1996). The second specimen cited above is an extension of about 30 kilometers to the southeast of a site mapped by Cody (1996) adjacent to the Alaska Hwy. and is the southernmost yet known in the Territory.

\section{LENTIBULARIACEAE}

Utricularia minor L., Lesser Bladderwort - YUKON: Kluane National Park, in five inches water, muddy substrate, pond at Slims East Trailhead, $60^{\circ} 59.408^{\prime} \mathrm{N}$ $138^{\circ} 29.483^{\prime} \mathrm{W}$, P. Caswell 03-541, 28 July 2003 (DAO).

The specimen cited above is an extension of the known range of this uncommon species in the Territory of about
300 kilometers west of a site near the south end of the Canol Road (Cody 1996). It is new to Kluane National Park.

\section{Plantaginaceae}

Plantago eriopoda Torr., Saline Plantain - Yukon: dry gravel, edge of parking space, Burwash Landing Airport, $61^{\circ} 22.183^{\prime} \mathrm{N} 139^{\circ} 01.842^{\prime} \mathrm{W}$, P. Caswell 02319, 6 July 2002 (DAO).

The specimen cited above is an extension of the known range in the Territory of about 75 kilometers northwest of a site adjacent to the Alaska Hwy. northwest of Haines Junction (Cody 1996).

\section{RUBIACEAE}

Galium triflorum Michx., Sweet-scented Bedstraw YUKON: organic soil at edge of thicket on west-facing slope, east of Haines Hwy. at $\mathrm{Km} 152,60^{\circ} 02.970$ ' N $136^{\circ} 53.001$ 'W, P. Caswell 03-746, 21 Aug. 2003 (DAO).

This is a rare species in the Territory (Douglas et al. 1981). The specimen cited above is an extension of the known range of about 140 kilometers southeast of a site near the south end of Kluane Lake.

\section{CAPRIFOLIACEAE}

Lonicera involucrata (Richards.) Banks ex Spreng., Black Twinberry - YukON: Haines Junction, L. Fournier s.n., July 1958 (DAO).

The specimen cited above was likely collected from cultivated plants. In the Yukon, it is known only from persisting plantings.

\section{VALERIANACEAE}

Valeriana sitchensis Bong., Sitka Valerian - YuKON: Kluane National Park, moist organic soil, Plug Creek, $60^{\circ} 03.593^{\prime} \mathrm{N} 138^{\circ} 12.055^{\prime} \mathrm{W}$, P. Caswell 03-647, 29 July 2003 (DAO).

The specimen cited above is an extension of the known range in the Territory of about 25 kilometers to the southwest of a site mapped by Cody (1996).

\section{CAmpanulaceae}

Campanula rotundifolia L., Harebell - YUKON: Kluane National Park, open soil with Festuca altaica, Arcostaphylos uva-ursi, Juniperus communis, Shepherdia canadensis, Populus balsamifera, and Potentilla fruticosa, Fisher Glacier near Alsek River, 6007'54"N $138^{\circ} 12^{\prime} 23^{\prime \prime W}$, B. A. Bennett 03-1052, 8 July 2003 (B. A. Bennett Herbarium, photo DAO).

This species was considered rare in the Territory by Douglas et al. (1981). The specimen cited above is from the third site in Kluane National Park and is an extension of about 30 kilometers west of a site mapped by Cody (1996).

\section{ASTERACEAE}

Antennaria pulcherrima (Hook.) Greene, Showy Pussytoes - YukON: Watson River, near mouth by Carcross Dunes, 60 $11^{\prime} 05^{\prime \prime N} 134^{\circ} 44^{\prime} 16^{\prime \prime} \mathrm{W}$, B. A. Bennett \& R. Mulder 03-1308, 17 Aug. 2003 (DAO).

The specimen cited above is an extension of the known range in the Territory (Cody 1996) of about 125 kilometers west of a site in the vicinity of Teslin.

Arnica diversifolia Greene, Diverse Arnica - YUKON: Kluane National Park, scree with organic component, mountain slope, old weather station on nunatak north 
of Lowell Glacier, $60^{\circ} 18.297^{\prime} \mathrm{N} 138^{\circ} 34.503^{\prime} \mathrm{W}, P$. Caswell et al. 03-597, 29 July 2003 (DAO).

This is a rare species in the Territory (Douglas et al. 1981) where it was known from a site near the south end of Kluane Lake in Kluane National Park. The specimen cited above is a southward extension of the known range in the Park of about 75 kilometers.

Arnica latifolia Bong., Mountain Arnica - YUKON: Kluane National Park, Fisher Glacier near Alsek River, $45^{\circ}$ southwest-facing slope above Fisher Glacier, silty sandy soil, $60^{\circ} 08^{\prime} 03^{\prime \prime} \mathrm{N} 138^{\circ} 12^{\prime} 54^{\prime \prime} \mathrm{W}$, B. A. Bennett 03-1033, 7 July 2003 (DAO).

The specimen cited above is the fourth yet known in the Park and the most westerly yet known in the Territory (Cody 1996).

Artemisia tilesii Ledeb. s.l., Aleutian Mugwort YUKON: Kluane National Park, occasional on xeric rock outcrops in shallow soil on edge of extremely steep cliffs, also seen at base of mountain, Fisher Glacier near Alsek River, $60^{\circ} 08^{\prime} 06^{\prime \prime N} 138^{\circ} 12^{\prime} 42^{\prime \prime} \mathrm{W}$, B. A. Bennett 03-1022, 7 July 2003 (DAO).

The specimen cited above is an extension of the known range in the Park of about 30 kilometers to the west from a site in the extreme south. This specimen is a very distinct form with rounded leaflets and dark bracts and may represent a new variety.

Cirsium foliosum (Hook.) DC., Leafy Thistle, Elk Thistle - YuKOn: Beaver Pond on McIntyre Creek across from Kopper King, Whitehorse, $60^{\circ} 44.73 ' \mathrm{~N}$ $135^{\circ} 07.36^{\prime} \mathrm{W}$, G. Delaet, B. A. Bennett \& R. Mulder 03-1370, 29 Sept. 2003, (B. A. Bennett Herbarium, photo DAO).

The specimen cited above is from a site intermediate between sites adjacent to the South Canol Road and Haines Hwy. mapped by Cody (1996).

Erigeron grandiflorus Hook. ssp. arcticus A. E. Porsild, Large-flowered Daisy - YUKON: Kluane National Park, organic soil on south-facing slope of alpine meadow, Wade Mountain, $61^{\circ} 18.373^{\prime} \mathrm{N} 139^{\circ} 31.273^{\prime} \mathrm{W}$, P. Caswell 02-374, 7 July 2002 (DAO).

This species was not included in The Rare Plants of the Yukon (Douglas et al. 1981) because of its widespread range. The specimen cited above is a short distance northwest of the westernmost site mapped by Cody (1996) in the Kluane National Park.

Erigeron humilis Graham, Arctic-alpine Daisy - YUKON: Kluane National Park, south-facing alpine slope, nunatak (abandoned weather station) north of Lowell Glacier, $60^{\circ} 18.297^{\prime} \mathrm{N} 138^{\circ} 34.503^{\prime} \mathrm{W}, P$. Caswell 03591, 29 July 2003 (DAO).

The specimen cited above is the most southwesterly yet known in Kluane National Park (Cody 1996). The nearest known site is about 25 kilometers to the northeast.

Erigeron peregrinus (Banks ex Pursh) Greene ssp. peregrinus, Subalpine Daisy - YUKON: Kluane National Park, moist organic soil, meadow, Plug Creek, $60^{\circ}$ $03.593^{\prime} \mathrm{N} 138^{\circ} 12.055^{\prime} \mathrm{W}$, P. Caswell et al. 03-651, 29 July 2003 (DAO).

This subspecies was considered rare in the Territory by Douglas et al. (1981). The specimen cited above is an ex- tension of the known range in the Territory of about 30 kilometers west of a site near the British Columbia border.

Erigeron pumilus Nutt., Shaggy Fleabane - Yukon: Kluane National Park, Donjek Valley, $61^{\circ} 00^{\prime} \mathrm{N} 139^{\circ}$ 22.573'W, R. Maraj s.n., 15 July 2002 (DAO).

Douglas et al. (1981) reported this species as rare in the Yukon Territory on the basis of a specimen collected in the vicinity of Kluane Lake. The specimen cited above is only the second known in the Territory. It was collected about 65 kilometers to the southwest and is a new record for Kluane National Park.

Erigeron uniflorus L. ssp. eriocephalus (Vahl ex Hornem.) Cronq., Northern Daisy - YUKON: Kluane National Park, alpine scree slope, nunatak at Logan Warden Cabin, $60^{\circ} 46.889^{\prime} \mathrm{N} 140^{\circ} 45.108^{\prime} \mathrm{W}$, P. Caswell et al. 03-264, 11 July 2003 (DAO).

Douglas et al. (1981) considered this species rare in the Territory. The specimen cited above which is about 50 kilometers southwest of the westernmost mapped by Cody (1996) in Kluane National Park is now the westernmost yet known in the Park.

Erigeron yukonensis Rydb., Yukon Fleabane - YukON: organic soil, flat burned area of dead Picea glauca, Copper Joe Creek, $61^{\circ} 18.641^{\prime} \mathrm{N} 138^{\circ} 56.324^{\prime} \mathrm{W}, P$. Caswell 02-156, 24 June 2002 (DAO); barren ridge, $50 \%$ vegetative coverage, east-facing slope $2^{\circ}$, inorganic soil with Dryas intergrifolia ssp. intergrifolia and Saxifraga tricuspidata, Thunder Egg Mountain, collected by Z. Mattson $60^{\circ} 47.777^{\prime} \mathrm{N} 137^{\circ} 46.993^{\prime} \mathrm{W}, P$. Caswell 04-058 (Kluane Park Herbarium, photo DAO).

This species is an endemic of the Yukon Territory and adjacent District of Mackenzie (Cody 1996). The first specimen cited above is an extension of the known range in the Territory of about 100 kilometers northwest of a site in Kluane National Park southwest of Haines Junction.

Hieracium gracile Hook., Slender Hawkweed YUKON: Kluane National Park, Fisher Glacier near Alsek River, west-facing slope above valley glacier leading into Fisher Glacier, $60^{\circ} 08^{\prime} 16^{\prime \prime} \mathrm{N} 138^{\circ} 13^{\prime} 28^{\prime \prime} \mathrm{W}$, B. A. Bennett 03-987, 7 July 2003 (DAO).

The specimen cited above is an extension of the known range about 35 kilometers west of the southernmost previously known to Cody (1996) in the Park.

Symphyotrichum ciliatum (Lindl.) A. \& D. Löve (Aster brachyactis Blake) Rayless Aster, Lindley's American Aster - YUKON: growing in silty saline mud along east shore and amongst Puccinellia, Triglochin palustris, Triglochin maritima and Lomatagonium rotatum, Fox Creek saline flat $600 \mathrm{~m}$ south of Fox Creek, Km 227 on east side of North Klondike Hwy., B. A. Bennett \& R. Mulder 03-1341, 13 Sept. 2003 (DAO).

Douglas et al. (1981) considered this species rare in the Territory on the basis of a single site at an alkaline meadow adjacent to the Takhini River west of Whitehorse. The specimen cited above from north of Whitehorse is from only the second known site in the Territory.

Symphyotrichum yukonense (Cronquist) Nelson (Aster yukonensis Cronquist), Yukon Aster, Yukon-American Aster - YUKON: silty broad alkaline river flat, northwest side of Donjek River, $61^{\circ} 40.8^{\prime} \mathrm{N} 139^{\circ} 45.58^{\prime} \mathrm{W}$, 
B. A. Bennett, R. Elven \& H. Solstad 03-053, 8 Aug. 2003 (DAO).

This species was considered rare in the Territory by Douglas et al. (1981). The specimen cited above is an extension of the known range in the Territory of about 100 kilometers northwest of sites in the vicinity of the south end of Kluane Lake.

Taraxacum lyratum (Ledeb.) DC., Rock Dandelion YUKON: Kluane National Park, Fisher Glacier near Alsek base camp, occasional in valley bottom in heath tundra, $60^{\circ} 08^{\prime} 311^{\prime \prime N} 138^{\circ} 13^{\prime} 13^{\prime \prime} \mathrm{W}, B$. A. Bennett 03-956, 6 July 2003 (DAO).

The specimen cited above is from the southernmost site yet found in the Park. It is from a site about 30 kilometers south of the southernmost previously known to Cody (1996).

\section{Acknowledgments}

We thank Gerald A. Mulligan for the identification of Brassicaceae (Cruciferae) specimens; George Argus for the identification of Salix niphoclada; Stephen Darbyshire for identification of Agrostis humilis, Festuca brachyphylla, Bromus japonicus, and Rumex maritimus ssp. fheginus; M. Barkworth for identification of Psathyrostachys juncea; Paul Catling for identification of Carex lasincarpa; Julie A. Dragon for identification of Carex lenticularis var. dolia; R. Elven and $\mathrm{H}$. Solstad for the identification of Papaver radicatum ssp. kluanensis, R. Elven for the identification of Stellaria umbellata; A. A. Reznicek for identification of several species of Carex; M. Costea for identification of Polygonum achoreum; Paul Catling for reviewing an earlier version of this manuscript and Leslie Cody for the many hours inputting this information on her computer.

\section{Literature Cited}

Britton, N. L., and P. A. Rydberg. 1901. Contributions to the botany of the Yukon Territory. 4. An enumeration of the flowering plants collected by R. S. Williams and J. B. Tarleton. Bulletin of the New York Botanical Garden 2: 149-187.

Calder, J. A., and D. B. O. Savile. 1960. Studies in Saxifragaceae III. Saxifraga odontoloma and lyallii, and North American subspecies of S. punctata. Canadian Journal of Botany 38: 409-435.

Cody, W. J. 1994. The flora of the Yukon Territory: Additions, Range Extensions and Comments. Canadian FieldNaturalist 108: 428-476.

Cody, W. J. 1996. Flora of the Yukon Territory. National Research Council (NRC) Press, Ottawa, Ontario, Canada. 643 pages.

Cody, W. J., C. E. Kennedy, and B. A. Bennett. 1998. New records of vascular plants in the Yukon Territory. Canadian Field-Naturalist 112: 289-328.

Cody, W. J., C. E. Kennedy, and B. A. Bennett. 2000. New records of vascular plants in the Yukon Territory II. Canadian Field-Naturalist 114: 417-443.

Cody, W. J., C. E. Kennedy, and B. A. Bennett. 2001. New records of vascular plants in the Yukon Territory III. Canadian Field-Naturalist 115: 301-322.
Cody, W. J., C. E. Kennedy, B. A. Bennett, and P. Caswell. 2004. New records of vascular plants in the Yukon Territory VI. Canadian Field-Naturalist 118: 558-578.

Cody, W. J., C. E. Kennedy, B. A. Bennett, and V. Loewen. 2002. New records of vascular plants in the Yukon Territory IV. Canadian Field-Naturalist 116: 446-474.

Cody, W. J., C. E. Kennedy, B. A. Bennett, and J. Staniforth. 2003. New records of vascular plants in the Yukon Territory V. Canadian Field-Naturalist 117: 278-301.

Cody, W. J., K. L. Reading, and J. M. Line. 1993. Additions and range extensions to the vascular plant flora of the Continental Northwest Territories and Nunavut, Canada II. Canadian Field-Naturalist 117(3): 448-465.

Douglas, G. W., and G. Ruyle-Douglas. 1978. Contributions to the floras of British Columbia and the Yukon Territory 1, Canadian Journal of Botany 56: 2296-2302.

Douglas, G. W., G. W. Argus, H. L. Dickson, and D. F. Brunton. 1981. The rare vascular plants of the Yukon. Syllogeus 28: 1-96.

Douglas, G. W., D. Meidinger, and J. Pojar. 1998-2001. Illustrated flora of British Columbia. Volumes 1-6.

Egger, M. 1992. Yukon Territory, Castilleja miniata Douglas ex. Hook. (Scrophulariaceae). Madrono 39: 244.

Hultén, E. 1940. History of botanical exploration in Alaska and Yukon territories from the time of their discovery to 1940. Botaniska Notiser 1940: 289-346.

Hultén, E. 1968. Flora of Alaska and neighboring territories. Stanford University Press, Stanford, California.

Kartesz, J. T., and C. A. Meacham. 1999. Synthesis of the North American Flora Version 1.0. North Carolina Botanical Garden, Chapel Hill, North Carolina.

Murray, D. F. 1995. New names in Papaver Section Meconella (Papaveraceae), Novon 5: 294-295.

Porsild, A. E., and W. J. Cody. 1980. Vascular plants of continental Northwest Territories, Canada. National Museum of Natural Sciences, Ottawa, Ontario. 667 pages.

Reznicek, A. A. 2002. 26j. Carex Linnaeus sect. Ammoglodrin Dumortier, Fl. Belg., 146. 1827. Pages 306-307 in Flora of North American, North of Mexico. Edited by The Flora of North America Editorial Committee. Volume 23, Magnoliophyta: Commelinidae (inpart): Cyperaceae. Oxford University Press, New York.

Standley, L. A., J. Cayouette, and L. Bruederle. 2002. 26r. Carex Linnaeus sect. Phacocyslis Dumortier, Fl. Belg., 146. 1827. Pages 379-401 in Flora of North America, north of Mexico. Edited by The Flora of North America Editorial Committee. Volume 23, Magnoliophyta: Commelinidae (in part): Cyperaceae. Oxford University Press, New York.

Utech, F. H. 2002. Pages 50-409 in Liliaceae. Flora North America, north of Mexico. Edited by The Flora of North America Editorial Committee. Volume 26: 50-409.

Welsh, S. L. 1974. Anderson's Flora of Alaska and Adjacent Parts of Canada. Brigham Young University Press, Provo, Utah, USA. 727 pages.

Welsh, S. L. 2001. Revision of North American species Oxytropis, de Candolle "Leguminose". Brigham Young University Press, Provo, Utah, USA 101 pages.

Received 5 May 2005

Accepted 23 July 2005 